\title{
Covalent Allosteric Probe for the Metabotropic Glutamate Receptor 2: Design, Synthesis, and Pharmacological Characterization
}

\author{
Maarten L. J. Doornbos, ${ }^{\dagger}$ Xuesong Wang, ${ }^{\dagger}$ Sophie C. Vermond, ${ }^{\dagger}$ Luc Peeters, ${ }^{\ddagger}$ Laura Pérez-Benito, ${ }^{\S}, \|$ \\ Andrés A. Trabanco, ${ }^{\S}$ Hilde Lavreysen, ${ }^{\ddagger}$ José María Cid, ${ }^{\S}$ Laura H. Heitman, ${ }^{\dagger}$ Gary Tresadern, ${ }^{*}, \S 0$ \\ and Adriaan P. IJzerman* ${ }^{\dagger}$ (1)
}

${ }^{\dagger}$ Division of Drug Discovery and Safety, Leiden Academic Centre for Drug Research (LACDR), Leiden University, P.O. Box 9502, 2300RA Leiden, The Netherlands

Janssen Research and Development, Turnhoutseweg 30, 2340 Beerse, Belgium

${ }^{\S}$ Janssen Research and Development, Calle Jarama 75A, 45007 Toledo, Spain

"Laboratori de Medicina Computacional Unitat de Bioestadistica, Facultat de Medicina, Universitat Autonoma de Barcelona, 08193 Bellaterra, Spain

\section{Supporting Information}

ABSTRACT: Covalent labeling of G protein-coupled receptors (GPCRs) by small molecules is a powerful approach to understand binding modes, mechanism of action, pharmacology, and even facilitate structure elucidation. We report the first covalent positive allosteric modulator (PAM) for a class $\mathrm{C}$ GPCR, the $\mathrm{mGlu}_{2}$ receptor. Three putatively covalent $\mathrm{mGlu}_{2}$ PAMs were designed and synthesized. Pharmacological characterization identified 2 to bind the receptor covalently. Computational modeling combined with receptor mutagenesis revealed $\mathrm{T} 791^{7.29 \times 30}$ as the likely position of covalent interaction. We show how this covalent ligand can be used to characterize the PAM binding mode and that it is a valuable tool compound in studying receptor function and binding kinetics. Our findings advance the understanding of the $\mathrm{mGlu}_{2}$ PAM interaction and suggest that $\mathbf{2}$ is a valuable probe for further structural and chemical biology approaches.

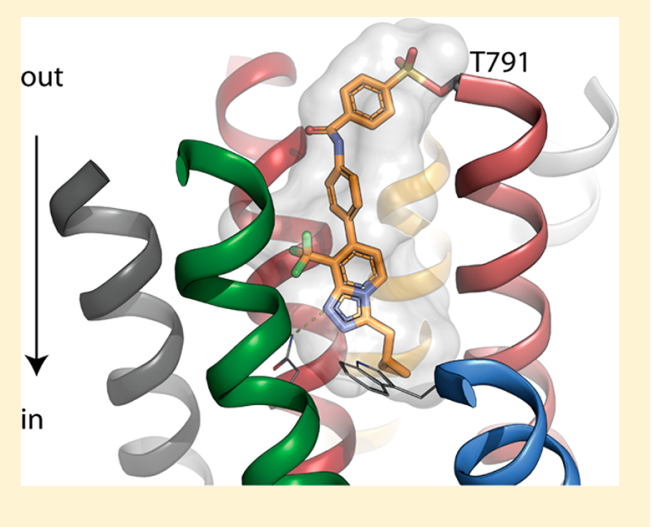

\section{INTRODUCTION}

Over the past years covalent ligands for G protein-coupled receptors (GPCRs) have re-emerged as valuable tool compounds to characterize the structure, expression pattern, and function of these proteins. ${ }^{1}$ A major obstacle in GPCR structure elucidation using crystallization is the dynamic behavior of their seven-transmembrane (7TM) domain, especially when in the active state. ${ }^{2}$ Covalent ligands can stabilize the 7TM domain of the receptor without the likelihood of dissociation from the binding site. The use of covalent ligands for structure elucidation has been taken as an approach to facilitate receptor crystallization, as was shown recently for the crystal structures of the adenosine $A_{1}$ and multiple $\beta 2$ adrenergic receptors among others. ${ }^{3,4}$ Beyond structural considerations, covalent molecules are valuable pharmacological tools useful for further understanding of binding modes and other chemical biology and proteomics applications.

The metabotropic glutamate ( $\mathrm{mGlu}$ ) receptors belong to the class C GPCRs and are activated by glutamate, the most abundant neurotransmitter. ${ }^{5}$ The mGlu receptors are obligatory dimers and are characterized by their large extracellular Venus flytrap (VFT) domain (binding endogenous glutamate) which is connected to the 7TM domain via a cysteine rich domain. ${ }^{6}$
For mGlu receptors, allosteric modulators that bind in the 7TM domain are pursued widely for drug discovery as they are typically more subtype-selective than orthosteric ligands and only function in the presence of endogenous agonist. ${ }^{7}$ Positive allosteric modulation of the $\mathrm{mGlu}_{2}$ receptor has been shown to be a potential strategy for the treatment of neurological disorders such as schizophrenia and anxiety. ${ }^{8}$ Although the structure of the extracellular domain of the $\mathrm{mGlu}_{2}$ receptor is known, ${ }^{9}$ the current understanding of the structure of the 7TM domain is based on the crystal structures of the $\mathrm{mGlu}_{1}$ and $\mathrm{mGlu}_{5} 7 \mathrm{TM}$ domains, which were crystallized in an inactive state with a negative allosteric modulator (NAM) bound in the allosteric binding pocket. ${ }^{10-12}$

We have had a long-standing interest in $\mathrm{mGlu}_{2}$ receptor PAMs leading to characterization of multiple medicinal chemistry series ${ }^{13,14}$ that were also studied with site-directed mutagenesis. ${ }^{15,16}$ We have further characterized the binding kinetics and pharmacology of selected leads. ${ }^{17-19}$ Robust in vivo pharmacodynamic effects were observed in several animal

Special Issue: Allosteric Modulators

Received: January 12, 2018

Published: March 1, 2018 

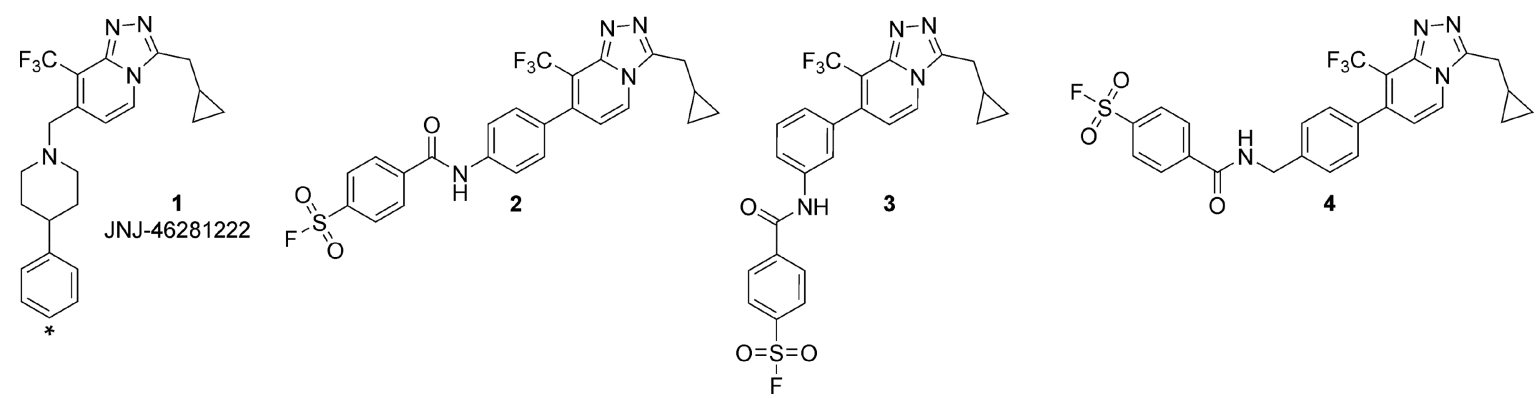

Figure 1. Structures of 1 and novel mGlu 2 PAMs 2-4. The position of the tritium label of $\left[{ }^{3} \mathrm{H}\right]-1$ is denoted by $*$.

Scheme 1. Synthesis of Compounds $2-4^{a}$

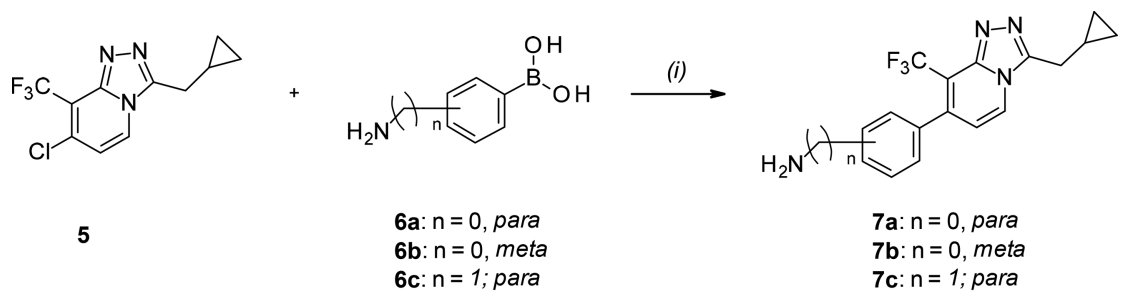

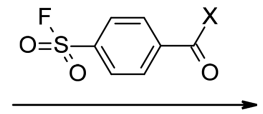

(ii)

$8 \mathrm{a}: \mathrm{X}=\mathrm{OH}$

$8 \mathbf{b}: \mathrm{X}=\mathrm{Cl}$

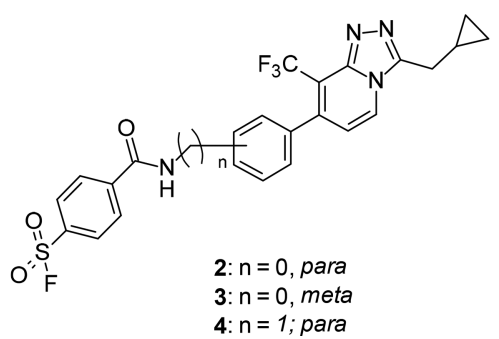

${ }^{a}$ Reagents and conditions: (i) $\mathrm{Pd}\left(\mathrm{PPh}_{3}\right)_{4}, \mathrm{NaHCO}_{3}, \mathrm{H}_{2} \mathrm{O} / 1$,4-dioxane, $150{ }^{\circ} \mathrm{C}, 10-15$ min, microwave, 61-68\% for 7a-c. (ii) (a) 8a, $\mathrm{HATU}$, DIPEA, DMF, rt, 3h, 68-75\% for 2 and 3, (b) 8b, 1,4-dioxane, $90{ }^{\circ} \mathrm{C}, 30 \mathrm{~min}, 33 \%$ for 4 .

Table 1. Functional Activity $\left(\mathrm{pEC}_{50}\right)$, Affinity $\left(\mathrm{pK}_{\mathrm{i}}\right)$, and Kinetic Parameters $\left(k_{\mathrm{on}}, k_{\mathrm{off}}, \mathrm{RT}\right)$ for mGlu 2 PAMs 1-4

\begin{tabular}{|c|c|c|c|c|c|c|}
\hline compd & $\mathrm{pEC}_{50}{ }^{a}$ & $\mathrm{p} K_{\mathrm{i}}^{a}$ & $\mathrm{p} K_{\mathrm{i}}(3 \mathrm{~h} \text { pre-incubation })^{a}$ & $k_{\mathrm{on}}\left(\mathrm{M}^{-1} \mathrm{~s}^{-1}\right)^{a}$ & $k_{\mathrm{off}}\left(\mathrm{s}^{-1}\right)^{a}$ & $\mathrm{RT}(\min )^{a, b}$ \\
\hline 1 & $7.74 \pm 0.03$ & $8.12 \pm 0.13$ & $8.12 \pm 0.19$ & $(1.2 \pm 0.072) \times 10^{6 c}$ & $0.0013 \pm 0.0002^{c}$ & $12 \pm 2.3^{c}$ \\
\hline 2 & $6.80 \pm 0.06$ & $7.21 \pm 0.11$ & $8.21 \pm 0.14^{*}$ & $"(3.2 \pm 1.2) \times 10^{3 "}$ & $"(3.2 \pm 3.1) \times 10^{-13 "}$ & $"(5.2 \pm 4.9) \times 10^{10 "}$ \\
\hline 3 & $6.80 \pm 0.04$ & $6.95 \pm 0.11$ & $6.78 \pm 0.09$ & $(2.1 \pm 0.77) \times 10^{4}$ & $0.00091 \pm 0.00033$ & $18 \pm 6.7$ \\
\hline 4 & $7.82 \pm 0.06$ & $8.24 \pm 0.08$ & $8.38 \pm 0.10$ & $(2.2 \pm 0.17) \times 10^{5}$ & $0.00057 \pm 0.00016$ & $29 \pm 8.3$ \\
\hline
\end{tabular}

${ }^{a}$ Values represent the mean \pm SEM of at least three individual experiments, performed in duplicate. ${ }^{b} \mathrm{RT}(\mathrm{min})=1 /\left(60 \times k_{\text {off }}\right) .{ }^{c}$ As described previously. ${ }^{17} *<0.01$, unpaired Student's $t$ test compared to co-incubation.

models with some molecules such as 1-butyl-3-chloro-4-(4phenyl-1-piperidinyl)-(1H)-pyridone (JNJ-40411813/ ADX71149) advancing to human clinical trials. ${ }^{20-23}$ Despite this, further and more rigorous approaches to understand $\mathrm{mGlu}_{2}$ PAM binding and receptor pharmacology are needed. In this study we have designed and synthesized three novel putatively covalent $\mathrm{mGlu}_{2}$ PAMs based on computational approaches and previous understanding of the PAM binding mode. These compounds were fully characterized in vitro, resulting in the identification of 4-[[4-[3-(cyclopropylmethyl)8-(trifluoromethyl) [1,2,4] triazolo[4,3-a]pyridin-7-yl]phenyl]carbamoyl] benzenesulfonyl fluoride (2) as a covalently binding $\mathrm{mGlu}_{2}$ PAM. The binding mode was studied using computational docking, which identified several amino acid residues that potentially formed the covalent interaction. Using site-directed mutagenesis, $\mathrm{T} 791^{7.29 \times 30}$ was confirmed as the residue responsible for the covalent interaction.

\section{RESULTS AND DISCUSSION}

Chemistry. On the basis of a series of analogues of 3(cyclopropylmethyl)-7-[(4-phenyl-1-piperidinyl)methyl]-8-(trifluoromethyl)-1,2,4-triazolo[4,3-a]pyridine (1, JNJ$46281222),{ }^{24}$ we recently developed a novel series of $\mathrm{mGlu}_{2}$ PAMs bearing the 7-aryl-1,2,4-triazolo[4,3-a]pyridine as the core structure. $^{13,17}$ This scaffold was used to design three novel putative covalent $\mathrm{mGlu}_{2}$ PAMs for which the fluorosulfonyl moiety was chosen as a reactive warhead. A 4-fluorosulfonylphenyl ring was connected to the 7-phenyl-1,2,4-triazolo[4,3a]pyridine-core via an amide linker to the phenyl ring at the 4position (2), the 3-position (3), or the 4-position with a methylene spacer in between to increase flexibility (4), as depicted in Figure 1. The synthesis of target compounds $\mathbf{2 - 4}$ is shown in Scheme 1. They were prepared via Suzuki coupling of the 7-chlorotriazolopyridine $\mathbf{5}^{25}$ with the corresponding commercially available boronic acids $(6 \mathbf{a}-\mathbf{c})$ and subsequent amide formation of $7 \mathbf{a}-\mathbf{c}$ with the commercially available 

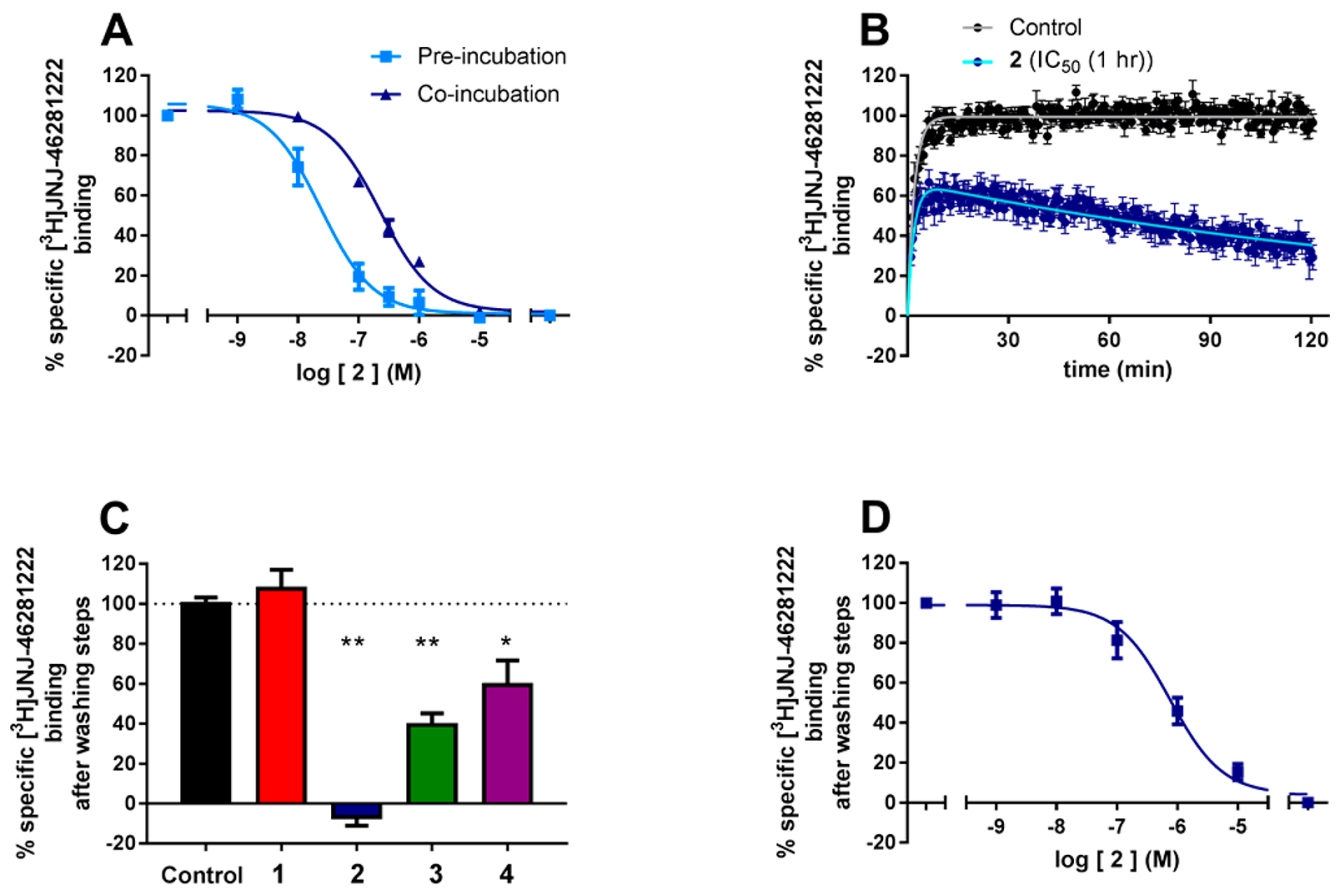

Figure 2. (A) Displacement of $\left[{ }^{3} \mathrm{H}\right] \mathrm{JNJ}-46281222$ by 2 with and without a pre-incubation of $3 \mathrm{~h}$. (B) Competition association assay of 2 at its $\mathrm{IC}_{50}$ concentration determined in the co-incubation assay. (C) $\left[{ }^{3} \mathrm{H}\right] \mathrm{JNJ}-46281222$ binding after pre-incubation with a $10 \times \mathrm{IC}_{50}$ concentration of mGlu ${ }_{2}$ PAM followed by four extensive washing cycles. (D) [ $\left.{ }^{3} \mathrm{H}\right] \mathrm{JNJ}-46281222$ binding after pre-incubation with increasing concentrations of 2 followed by four extensive washing cycles. Data represent the mean \pm SEM of at least three individual experiments performed in duplicate: $(*) p<0.01 ;(* *) p$ $<0.0001$, one-way ANOVA with Dunnett's post-test compared to control.

chemoreactive group. This electrophilic fluorosulfonyl moiety was chosen as a warhead to achieve a covalent interaction with a nucleophilic amino acid at the allosteric binding pocket of the $\mathrm{mGlu}_{2}$ receptor. This moiety has been widely used and was chosen for its wide reactivity to various nucleophilic residues: serine, threonine, tyrosine, lysine, cysteine, and histidine. ${ }^{26}$

Biology and Structure-Reactivity Considerations. First, the potency of the compounds to enhance the effect of glutamate at its $\mathrm{EC}_{20}$ was determined using a $\left[{ }^{35} \mathrm{~S}\right] \mathrm{GTP} \gamma \mathrm{S}$ assay. Reference PAM 1 showed a high potency (Table 1; $\left.\mathrm{pEC}_{50}=7.74 \pm 0.03\right)$. Compounds $2-4$ were all able to increase the response of the $\mathrm{EC}_{20}$ glutamate concentration to a similar level as $\mathbf{1}$ and thus behaved as functional $\mathrm{mGlu}_{2}$ PAMs with potencies of around $100 \mathrm{nM}$ for 2 and $3\left(\mathrm{pEC}_{50}\right.$ values of $6.80 \pm 0.06$ and $6.80 \pm 0.04$, respectively). The highest potency was found for 4 , with a $\mathrm{pEC}_{50}$ value of $7.82 \pm 0.06$.

Subsequently, the apparent affinities of the compounds were determined in a $\left[{ }^{3} \mathrm{H}\right] \mathrm{JNJ}-46281222$ displacement assay (Table 1 ). The $\mathrm{p} K_{\mathrm{i}}$ value of $8.12 \pm 0.19$ for 1 was close to its $\mathrm{pEC}_{50}$ value. Also, 2 and 3 had $\mathrm{p} K_{\mathrm{i}}$ values close to their $\mathrm{pEC}_{50}$ values, $7.21 \pm 0.11$ and $6.95 \pm 0.11$, respectively. Compound 4 had the highest affinity with a $\mathrm{p} K_{\mathrm{i}}$ value of $8.24 \pm 0.08$.

The $\mathrm{pEC}_{50}$ and $\mathrm{p} K_{\mathrm{i}}$ values $(7.74 \pm 0.03$ and $8.12 \pm 0.13$, respectively) of 1 were similar to those reported before. ${ }^{18}$ The potency and affinity parameters of $2-4$ compared favorably with the well-studied 1 , which was one of the most potent compounds identified from the same triazolopyridine scaffold and was used as a control throughout the study. Even though the fluorosulfonyl moiety at the distal tail in $2-4$ was more bulky and hydrophilic than the unsubstituted phenyl of $\mathbf{1}$ and the other compounds studied previously, ${ }^{17,24}$ the affinity and potency values were only reduced approximately 10-fold for 2 and 3 compared to $\mathbf{1}$ and not at all for 4 . The shift of the 4- fluorosulfonylphenyl ring from the 4-position in 2 to the 3position in 3 did not change the potency and affinity, whereas the greater flexibility of the methylene spacer in 4 most likely resulted in its increased potency and affinity compared to 2 . Selectivity of this series of $\mathrm{mGlu}_{2}$ PAMs was good. Representative 3 showed no activity at $\mathrm{mGlu}_{1,3,5,8}$ (Table S1 in Supporting Information).

Since a covalent interaction would induce insurmountable binding to the allosteric binding site, we set up a radioligand displacement assay using a $3 \mathrm{~h}$ pre-incubation of $\mathrm{CHO}$ $\mathrm{K} 1 \mathrm{hmGlu}_{2}$ membranes with increasing concentrations of the four PAMs. This pre-incubation was followed by addition of $\left[{ }^{3} \mathrm{H}\right] \mathrm{JNJ}-46281222$ and a subsequent incubation for $1 \mathrm{~h}$. Data were compared to the control experiments with no preincubation, i.e., co-incubation of the radioligand and the compounds studied.

Compound 1 showed no difference in affinity between the co-incubation and the pre-incubation assays (Table $1 ; \mathrm{p} K_{\mathrm{i}}=$ 8.12 in both cases), indicating that 1 does not bind insurmountably to the allosteric binding pocket. On the contrary, the addition of a pre-incubation step resulted in a 10 -fold increase in affinity for $\mathbf{2}$ (Table 1 ; Figure 2A), indicating that this compound binds the receptor insurmountably as no re-equilibration of 2 occurred after addition of $\left[{ }^{3} \mathrm{H}\right] J \mathrm{NJ}$ 46281222. Both 3 and 4 did not reveal a significant shift in receptor affinity when tested in the two-step binding assay, indicating they do not bind the receptor insurmountably. The observation of a shift in affinity of $\mathbf{2}$ after pre-incubation is in agreement with previously described covalent ligands for the histamine $\mathrm{H}_{4}$ and adenosine $\mathrm{A}_{2 \mathrm{~A}}$ receptors. ${ }^{27,28}$

Competition binding experiments are generally not the preferred method for evaluation of covalent interactions with GPCRs. $^{29,30}$ Therefore, the kinetic parameters $k_{\text {on }}$ and $k_{\text {off }}$ of 

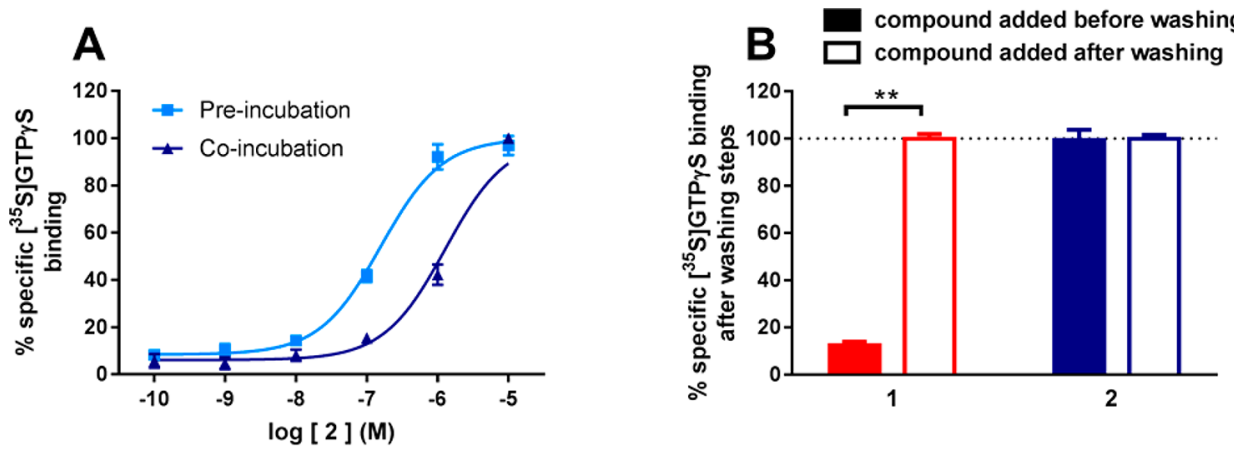

Figure 3. (A) Compound-induced $\left[{ }^{35} \mathrm{~S}\right] \mathrm{GTP} \gamma \mathrm{S}$ binding after $60 \mathrm{~min}$ of incubation with $\left[{ }^{35} \mathrm{~S}\right] \mathrm{GTP} \gamma \mathrm{S}$ with or without a $3 \mathrm{~h}$ pre-incubation in the presence of a glutamate concentration equivalent to its $\mathrm{EC}_{20}$ value. (B) $\left.{ }^{35} \mathrm{~S}\right] \mathrm{GTP} \gamma \mathrm{S}$ binding after stimulation with a $10 \times \mathrm{IC}_{50}$ concentration of $\mathrm{mGlu}_{2}$ PAM which was added either before or after four extensive washing cycles. All experiments were performed in the presence of a glutamate concentration equivalent to its $\mathrm{EC}_{20}$ value. Data represent the mean $\pm \mathrm{SEM}$ of at least three individual experiments performed in duplicate: $(* *) p<$ 0.0001 , unpaired Student's $t$ test.

1-4 were determined (Table 1). The kinetic parameters for $\mathbf{1}$ were determined in classical $\left[{ }^{3} \mathrm{H}\right] \mathrm{JNJ}-46281222$ association and dissociation experiments, yielding the association rate constant $k_{\text {on }}\left(k_{1}=1.2 \times 10^{6} \mathrm{M}^{-1} \mathrm{~s}^{-1}\right)$ and dissociation rate constant $k_{\text {off }}$ $\left(k_{2}=0.0013 \mathrm{~s}^{-1}\right)$, leading to a residence time (RT) of $12 \mathrm{~min}$. Using these values, we determined the kinetic $k_{\text {on }}\left(k_{3}\right)$ and $k_{\text {off }}$ $\left(k_{4}\right)$ values for 2-4 using a competition association assay based on the Motulsky and Mahan model. ${ }^{31}$ In contrast to $\mathbf{1}, 2$ showed a much slower on-rate $\left(3.2 \times 10^{3} \mathrm{M}^{-1} \mathrm{~s}^{-1}\right)$ and a negligible off-rate $\left(3.2 \times 10^{-13} \mathrm{~s}^{-1}\right)$, leading to an infinite RT, indicative for irreversible binding. The competition association curve of 2 shows an overshoot followed by a declining curve that did not reach equilibrium (Figure 2B). Compound 3 showed an on-rate of $2.1 \times 10^{4} \mathrm{M}^{-1} \mathrm{~s}^{-1}$ and an off-rate of $0.00091 \mathrm{~s}^{-1}$, leading to a RT of $18 \mathrm{~min}$, which is comparable to 1. The on-rate of 4 was 10 -fold faster $\left(2.2 \times 10^{5} \mathrm{M}^{-1} \mathrm{~s}^{-1}\right)$ and off-rate slower than $3\left(0.00057 \mathrm{~s}^{-1}\right)$, leading to a RT of $29 \mathrm{~min}$. The values for 3 and 4 indicate reversible binding behavior which is in line with the displacement experiments. The shape of the competition association curve of $\mathbf{2}$ (Figure $2 \mathrm{~B}$ ) is typical for an irreversible interaction, similar to that seen recently with the irreversibly binding FSCPX at the adenosine $\mathrm{A}_{1}$ receptor. ${ }^{32}$ As the values determined for $k_{\text {on }}$ and $k_{\text {off }}$ of $\mathbf{2}$ are far from the kinetic parameters of the radioligand and beyond the duration of the experiments, they should be considered approximate values. Still, this does not change the conclusion of an infinite RT. Furthermore, $\mathbf{2}$ can be used as a tool compound for studying binding kinetics of allosteric modulators at the $\mathrm{mGlu}_{2}$ receptor, a strategy that was followed before for the adenosine $\mathrm{A}_{1}$ receptor. $^{33}$

To distinguish between irreversible and pseudoirreversible interactions of 2-4, we performed radioligand binding assays followed by extensive washing steps. A washout assay was developed in which $1 \mathrm{~h}$ pre-incubation with a $10 \times \mathrm{IC}_{50}$ concentration of compound was followed by at least three extensive wash and centrifugation cycles. After the subsequent incubation with $\left[{ }^{3} \mathrm{H}\right] \mathrm{JNJ}-46281222$, radioligand displacement was assessed and compared to the control condition without any competitor (100\% radioligand binding). For 1 (unlabeled JNJ-46281222), no radioligand displacement was found, indicating that $\mathbf{1}$ was completely washed away (Figure 2C). For compounds 3 and 4, $\left[{ }^{3} \mathrm{H}\right] \mathrm{JNJ}-46281222$ was displaced partially, indicating that a portion of the receptor population was still bound but no persistent covalent interactions occurred. This partial recovery of $\mathbf{3}$ and $\mathbf{4}$ was likely caused by their slower binding kinetics compared to $\mathbf{1}$. Pre-incubation with compound 2 completely abolished $\left[{ }^{3} \mathrm{H}\right] \mathrm{JNJ}-46281222$ binding after the washing cycles, indicating its irreversible binding to the $\mathrm{mGlu}_{2}$ receptor (Figure $2 \mathrm{C}$ ). This was further confirmed by pre-incubation with increasing concentrations of 2 , followed by four extensive washing cycles. For this effect a concentrationresponse curve was established, with an apparent $\mathrm{p} K_{\mathrm{i}}$ value for 2 of $6.63 \pm 0.14$ which is another qualitative assessment of the irreversible interaction.

To evaluate the effect of irreversible binding of $\mathbf{2}$ on the functional PAM response, the following $\left[{ }^{35} \mathrm{~S}\right] \mathrm{GTP} \gamma \mathrm{S}$ setup was used. Increasing concentrations of $\mathbf{2}$ and a glutamate concentration equivalent to its $\mathrm{EC}_{20}$ value were preincubated with membranes for $3 \mathrm{~h}$, followed by a $1 \mathrm{~h}$ incubation with $\left[{ }^{35} \mathrm{~S}\right] \mathrm{GTP} \gamma \mathrm{S}$, resulting in a potency of $6.75 \pm 0.13$, which was $7-$ fold higher than when co-incubation only was performed $\left(\mathrm{pEC}_{50}=5.90 \pm 0.08\right)$ (Figure $\left.3 \mathrm{~A}\right)$. The $\mathrm{pEC}_{50}$ value determined after $3 \mathrm{~h}$ pre-incubation followed by $1 \mathrm{~h}$ coincubation with $\left[{ }^{35} \mathrm{~S}\right] \mathrm{GTP} \gamma \mathrm{S}(6.75 \pm 0.13)$ was similar to the potency assessed in the standard $\left[{ }^{35} \mathrm{~S}\right] \mathrm{GTP} \gamma \mathrm{S}$ protocol $(6.80 \pm$ 0.06), which also included a pre-incubation step.

The ability of bound 2 to behave as a PAM was studied by repeating the washout assay but with a $\left[{ }^{35} \mathrm{~S}\right] \mathrm{GTP} \gamma \mathrm{S}$ binding assay subsequent to the washing cycles (Figure 3B). Compound 2 was still able to induce $\left[{ }^{35} \mathrm{~S}\right] \mathrm{GTP} \gamma \mathrm{S}$ binding in the presence of an $\mathrm{EC}_{20}$ concentration of glutamate after the washing steps. The level was comparable to the control situation in which the compound was added after the washing steps. As a further control, the assay was also performed using 1, which did not induce $\left[{ }^{35} \mathrm{~S}\right] \mathrm{GTP} \gamma \mathrm{S}$ binding as it was washed away (Figure 2C), in contrast to the situation in which 1 was added after washing (Figure 3B).

Computational Modeling. It is well understood that allosteric modulators of mGlu receptors bind in the 7TM domain in a similar conserved site as class A GPCRs. ${ }^{7}$ Crystallography has shown variation in the exact location of allosteric ligands in this site. ${ }^{34}$ Our previous experimental and computational studies have helped to pinpoint the binding mode of $\mathrm{mGlu}_{2}$ receptor PAMs of several chemical series. ${ }^{15,16}$ This work greatly helped the design of molecules $2-4$. With a strong certainty that the triazolopyridine core binds deepest in the receptor, ${ }^{16,18}$ we designed and docked multiple different candidate fluorosulfonylphenyl molecules. Idea molecules were docked into a homology model of the $\mathrm{mGlu}_{2}$ receptor allosteric binding site using a model and approach as described 
previously. ${ }^{16,24}$ Due to flexibility and sequence differences, there is increased uncertainty of the amino acid position and conformation in the extracellular side of the receptor model. From the docking, 2-4 allowed the fluorosulfonyl to explore different vectors and depths of the extracellular side of the binding site. Our approach relying upon a model of the ligand receptor binding mode, and not a crystal structure, was more high risk. Therefore, we chose the fluorosulfonylphenyl as the warhead because it can react with various nucleophilic amino acids as to increase the chance to find a covalent ligand.

The docking results for molecule 2 showed the triazolopyridine core overlapped with that of $\mathbf{1}$ (Figure 4), which was

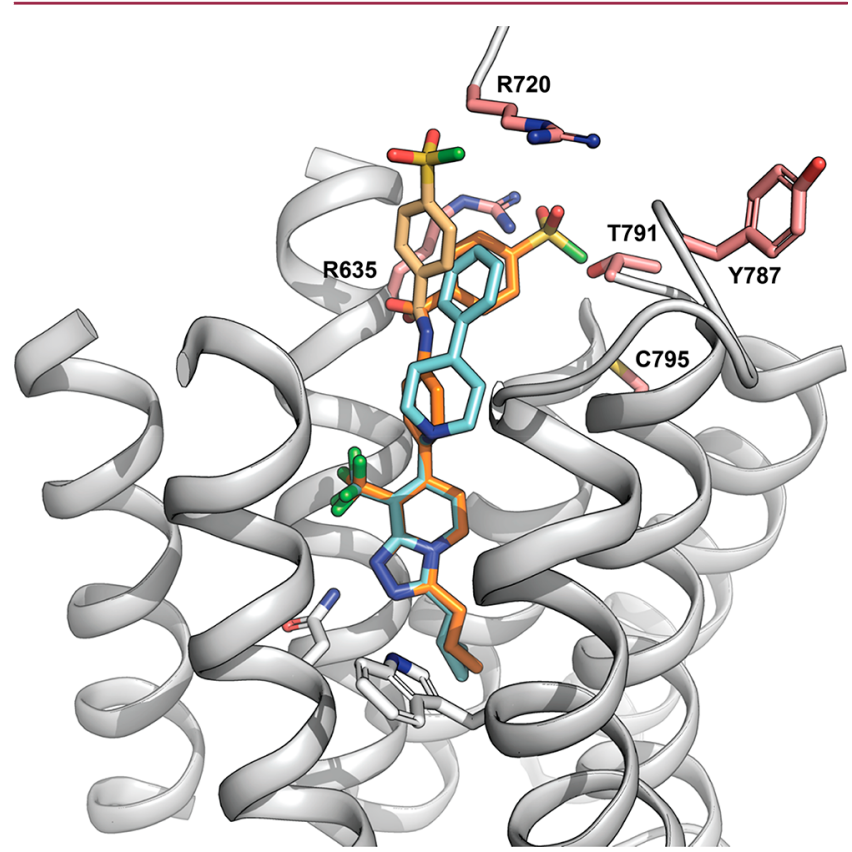

Figure 4. Proposed binding mode of mGlu $_{2}$ PAMs 1 (pale blue) and 2 (dark and pale orange). The two possible binding modes for $\mathbf{2}$ are distinguished using dark and pale orange coloring. The five amino acids chosen as possible candidates for the covalent interaction are highlighted in salmon color and labeled.

included in earlier reports. As mentioned, this positioning and orientation of the scaffold are consistent with previous SAR and mutagenesis work. ${ }^{35}$ The flexible distal tail of $\mathbf{2}$ containing the fluorosulfonyl moiety was pointing toward the top of transmembrane helix 3 or 7 and extracellular loop (ECL) 2 . As suggested by the $\mathrm{mGlu}_{1}$ structure, ECL2 forms a lid on top of the 7TM pocket in all class C GPCRs, which is likely happening to $\mathrm{mGlu}_{2}$ as well. ${ }^{10,36}$ While the scaffold consistently adopted the shown binding orientation, two different binding modes were possible for the distal part of the molecule (Figure 4). In the first binding mode, the distal phenyl relaxes into the 7TM of the receptor. This is analogous to the binding mode and behavior of $\mathbf{1}$ reported in previous computational studies, ${ }^{18}$ as shown comparing pale blue and dark orange molecules in Figure 4. The fluorosulfonyl moiety is presented close to T791 $1^{7.29 \times 30}$ located in our model at the top of TM-7. If the ligand maintains a more linear orientation, it will present a second possible binding mode as shown in pale orange in Figure 4, where the fluorosulfonyl group points toward two alternative arginines: R635 $5^{3.32 \times 32}$ and R720 (ECL2).

Receptor Mutagenesis. On the basis of the two potential binding modes of $\mathbf{2}$, multiple nucleophilic amino acid residues were within a radius of $4 \AA$ to the fluorosulfonyl warhead and hence were potential candidates to form the covalent bond with the fluorosulfonyl. Although arginines are not widely reported to behave as nucleophiles, the proximity of several in the extracellular region may permit some to be less protonated, and we therefore did not want to overlook this possibility. The amino acids included R635 $5^{3.32 \times 32}$ and R720 (ECL2) and T791 ${ }^{7.29 \times 30}$. Meanwhile, Y787 (ECL3) and C795 $7.33 \times 34$ were further away, but given the flexibility of the extracellular region of the receptor, they were still considered as possible candidates for interaction with the ligand warhead.

For all these five residues alanine substitutions were made. These $\mathrm{mGlu}_{2}$ receptor mutants were transiently transfected into $\mathrm{CHO}-\mathrm{K} 1$ cells, and membrane preparations were made.

Control experiments confirmed the integrity and function of the mutant receptors, as shown in the Supporting Information (Figure S1, Table S2). [ $\left.{ }^{3} \mathrm{H}\right] \mathrm{LY} 341495$ binding experiments were performed to assess the expression of transiently transfected WT and mutant $\mathrm{mGlu}_{2}$ receptors, revealing a similar affinity of glutamate for the WT and all mutants, which confirmed the integrity of the orthosteric binding pocket. All mutants were still able to induce $\left[{ }^{35} \mathrm{~S}\right] \mathrm{GTP} \gamma \mathrm{S}$ binding upon stimulation by glutamate with similar potencies, which confirmed the function of the receptor was maintained. Furthermore, all mutants were still able to bind $\left[{ }^{3} \mathrm{H}\right] J \mathrm{NJ}-$ 46281222, which was displaced by unlabeled 1 with similar affinities, which confirmed the integrity of the allosteric binding site (Figure S1, Table S2).

To evaluate which of the amino acid residues was responsible for covalent binding of 2 , the washout assay was repeated (Figure 5A). Compound $\mathbf{1}$ was used as a control and showed around maximal $\left[{ }^{3} \mathrm{H}\right] \mathrm{JNJ}-46281222$ binding after washing in all cases, confirming that 1 was washed away during the washing cycles. The transiently transfected $\mathrm{WT} \mathrm{mGlu}_{2}$ showed a similar effect of $\mathbf{2}$ after washing compared to the stable $\mathrm{CHO}$ $\mathrm{K} 1 \mathrm{hmGlu}{ }_{2}$ cell line, i.e., complete inhibition of $\left[{ }^{3} \mathrm{H}\right] \mathrm{JNJ}$ 46281222 binding. Mutants R635 $5^{3.32 \times 32} \mathrm{~A}, \mathrm{R} 720 \mathrm{~A}, \mathrm{Y} 787 \mathrm{~A}$, and $\mathrm{C} 795^{7.33 \times 34} \mathrm{~A}$ showed a similar negligible level of $\left[{ }^{3} \mathrm{H}\right] \mathrm{JNJ}-$ 46281222 binding, indicating that 2 was still binding covalently. However, T791 ${ }^{7.29 \times 30} \mathrm{~A}$ showed $\left[{ }^{3} \mathrm{H}\right] \mathrm{JNJ}-46281222$ binding to all available binding sites and thus a loss of covalent binding.

A full curve $\left[{ }^{3} \mathrm{H}\right] \mathrm{JNJ}-46281222$ displacement assay using the $\mathrm{T} 791^{7.29 \times 30} \mathrm{~A}$ mutant revealed a $\mathrm{p} K_{\mathrm{i}}$ for 2 of $6.45 \pm 0.03$ (Figure $5 \mathrm{C})$, which was similar to the transiently transfected WT $\mathrm{mGlu}_{2}$ receptor (Figure 5B; $6.76 \pm 0.04$ ) but lower than the $\mathrm{p} K_{\mathrm{i}}$ found at the CHO-K1 hmGlu ${ }_{2}$ membranes (Table 1). This discrepancy is likely caused by the difference in technique used, a filtration binding assay in contrast to an SPA assay.

The loss of irreversible interaction for the $\mathrm{T} 791^{7.29 \times 30} \mathrm{~A}$ mutant was further confirmed in the displacement assay, as the $\left[{ }^{3} \mathrm{H}\right] J \mathrm{NJ}-46281222$ displacement curves of 2 with and without pre-incubation step lost the large shift shown on the WT receptor (Figure 5C) and were almost overlapping for this mutant (Figure 5B), indicating a loss of insurmountable binding behavior. Together, these experiments indicated that $\mathrm{T} 791^{7.29 \times 30}$ was the residue responsible for making the covalent bond between the receptor and 2. A similar approach was used recently for the adenosine $A_{2 A}$ and neurotensin NTS1 receptors where a lysine and cysteine residue were found to be responsible for the covalent interaction, respectively. ${ }^{28,37}$ The position of the covalent bond was used to predict the binding mode of 2 , which further increased the understanding of the 

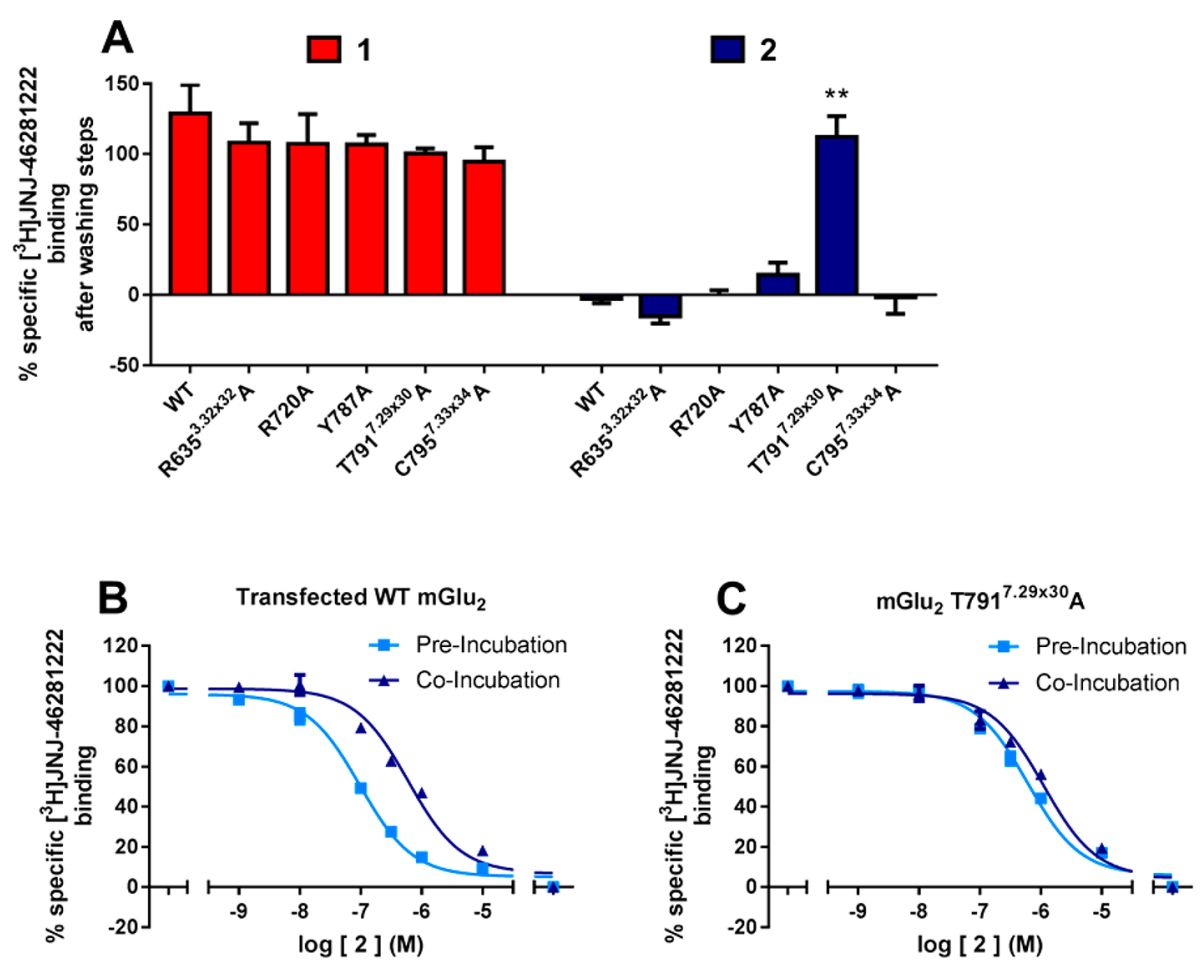

Figure 5. (A) $\left[{ }^{3} \mathrm{H}\right] \mathrm{JNJ}-46281222$ binding to transiently transfected $\mathrm{mGlu}_{2}$ mutants after pre-incubation with 1 or 2 at a $10 \times \mathrm{IC}_{50}$ concentration followed by four extensive washing cycles. (B) C.) Displacement of specific $\left[{ }^{3} \mathrm{H}\right] J N J-46281222$ binding from transiently transfected WT (B) and $\mathrm{T} 791^{7.29 \times 30} \mathrm{~A}(\mathrm{C}) \mathrm{mGlu}_{2}$ receptor by 2 with and without a pre-incubation of $3 \mathrm{~h}$. Experiments were performed in the presence of a glutamate concentration equivalent to its $\mathrm{EC}_{20}$ value. Data represent the mean $\pm \mathrm{SEM}$ of at least three individual experiments performed in duplicate: $(* *) p<$ 0.0001, one-way ANOVA with Dunnett's post-test compared to WT.

binding of PAMs to the binding pocket in addition to our recent mutagenesis and computational work. ${ }^{15,16,18}$

Compound 2 can be a useful structural biology tool as it would be expected to stabilize the 7TM domain in its active state, thereby potentially facilitating crystallization of the active state receptor. This could be highly valuable for structure elucidation of an active state of a class C GPCR which up to now remains unreported. Furthermore, there is no crystal structure of the 7TM domain of the $\mathrm{mGlu}_{2}$ receptor. Thus far, the crystal structures of class C 7TM domains were the NAM bound structures of $\mathrm{mGlu}_{1}$ and $\mathrm{mGlu}_{5}{ }^{10-12}$ A PAM bound structure would greatly enhance our understanding of the activation mechanism of class C GPCRs. Recently Gregory et al. (2016) published the first clickable covalent photoaffinity ligands for the $\mathrm{mGlu}_{5}$ receptor. ${ }^{38}$ These ligands are NAMs for the receptor and bind the receptor covalently upon photoactivation. The ligands contain an alkyne click handle that can be used for conjugation of clickable dyes. These probes can then be used for various purposes such as imaging in native tissues. ${ }^{38}$ Such a strategy is also of interest for the $\mathrm{mGlu}_{2}$ receptor, and $\mathbf{2}$ may be used as a starting point for further chemical optimization.

Covalent ligands have proved to be successful medicines for various indications, but due to safety concerns, they are mostly neglected in drug discovery. ${ }^{39}$ This is especially the case for neuroscience indications that often require chronic treatment, thus exacerbating such fears. Nevertheless, the introduction of covalent warheads into ligands that were optimized for noncovalent affinity may overcome some of the expected difficulties of off-target-activities. Such highly targeted, selective covalent inhibitors represent the current state of the art. ${ }^{40}$ Furthermore, covalent allosteric modulators are even more likely to be used as therapeutics compared to orthosteric ligands since they lack intrinsic efficacy, thereby avoiding problems due to on-target toxicity. ${ }^{41}$

\section{CONCLUSION}

This study reports the design, synthesis, and pharmacological characterization of the first covalent PAM for a class C GPCR. In addition, a combined computational and mutagenesis approach enabled the identification of $\mathrm{T} 791^{7.29 \times 30}$ as the position of the covalent interaction. Due to its favorable allosteric properties, this compound may be considered a tool compound to further evaluate the use of covalent ligands as potential GPCR therapeutics. Furthermore, it enhances the understanding of the binding mode of PAMs, may be considered a starting point of further development of a functionalized PAM probe, and could be a valuable tool compound for structure elucidation of the $\mathrm{mGlu}_{2}$ receptor.

\section{EXPERIMENTAL SECTION}

Chemistry. Unless otherwise noted, all reagents and solvents were obtained from commercial suppliers and used without further purification. Thin layer chromatography (TLC) was carried out on silica gel 60 F254 plates (Merck). Flash column chromatography was performed on silica gel, particle size $60 \AA$, mesh $=230-400$ (Merck), under standard techniques. Microwave assisted reactions were performed in a single-mode reactor, Biotage Initiator Sixty microwave reactor (Biotage), or in a multimode reactor, MicroSYNTH Labstation (Milestone, Inc.). Nuclear magnetic resonance (NMR) spectra were recorded with either a Bruker DPX-400 or a Bruker AV-500 spectrometer (Bruker AG) with standard pulse sequences NMR data operating at 400 and $500 \mathrm{MHz}$, respectively, using $\mathrm{CDCl}_{3}$ and DMSO$d_{6}$ as solvents. Chemical shifts $(\delta)$ are reported in parts per million (ppm) downfield from tetramethylsilane $(\delta=0)$. Coupling constants 
are reported in hertz. Splitting patterns are defined by s (singlet), d (doublet), dd (double doublet), $\mathrm{t}$ (triplet), q (quartet), quin (quintet), sex (sextet), sep (septet), or m (multiplet). Liquid chromatography combined with mass spectrometry (LC-MS) was performed on either a HP 1100 HPLC system (Agilent Technologies) or Advanced Chromatography Technologies system composed of a quaternary or binary pump with degasser, an autosampler, a column oven, a diode array detector (DAD), and a column as specified in the respective methods. Flow from the column was split to a MS spectrometer. The MS detector was configured with either an electrospray ionization source or an ES-CI dual ionization source (electrospray combined with atmospheric pressure chemical ionization). Nitrogen was used as the nebulizer gas. Data acquisition was performed with MassLynxOpenlynx software or with Chemstation-Agilent Data Browser software.

Compounds are described by their experimental retention times $\left(t_{\mathrm{R}}\right)$ and ions. The reported molecular ion corresponds to the $[\mathrm{M}+$ $\mathrm{H}]^{+}$(protonated molecule) and/or $[\mathrm{M}-\mathrm{H}]^{-}$(deprotonated molecule). Purities of all new compounds were determined by analytical RP-HPLC using the area percentage method on the UV trace recorded at a wavelength of $254 \mathrm{~nm}$, and compounds were found to have $\geq 95 \%$ purity unless otherwise specified. More detailed information about the different LC-MS methods employed can be found in the Supporting Information.

4-[[4-[3-(Cyclopropylmethyl)-8-(trifluoromethyl)[1,2,4]triazolo[4,3-a]pyridin-7-yl]phenyl]carbamoyl]benzenesulfonyl Fluoride (2). DIPEA $(0.079 \mathrm{~mL}, 0.4514 \mathrm{mmol})$ was added to a stirred solution of $7 \mathbf{a}(0.1 \mathrm{~g}, 0.301 \mathrm{mmol}), 8 \mathrm{a}(0.074 \mathrm{mg}, 0.3611 \mathrm{mmol})$, and HATU $(0.195 \mathrm{mg}, 0.512 \mathrm{mmol})$ in DMF $(2 \mathrm{~mL})$. The mixture was stirred at room temperature for $3 \mathrm{~h}$. The mixture was diluted with $\mathrm{CH}_{2} \mathrm{Cl}_{2}$ and washed with sat. $\mathrm{NH}_{4} \mathrm{Cl}$ and $\mathrm{NaHCO}_{3}$ aqueous saturated solution. The organic layer was separated, dried $\left(\mathrm{Na}_{2} \mathrm{SO}_{4}\right)$, filtered, and the solvents were evaporated in vacuo. The crude product was purified by flash column chromatography (silica; $\mathrm{CH}_{2} \mathrm{Cl}_{2}$ in $\mathrm{MeOH}$ $100 / 0$ to $94 / 6$ ). The desired fractions were collected and the solvents evaporated in vacuo to yield $2(0.116 \mathrm{~g}, 75 \%)$. ${ }^{1} \mathrm{H}$ NMR $(500 \mathrm{MHz}$, DMSO- $\left.d_{6}\right) \delta 10.84(\mathrm{~s}, 1 \mathrm{H}), 8.75(\mathrm{~d}, J=7.22 \mathrm{~Hz}, 1 \mathrm{H}), 8.22-8.41(\mathrm{~m}$, $4 \mathrm{H}), 7.93(\mathrm{~d}, J=8.38 \mathrm{~Hz}, 2 \mathrm{H}), 7.47(\mathrm{~d}, J=8.67 \mathrm{~Hz}, 2 \mathrm{H}), 6.97(\mathrm{~d}, J=$ $6.94 \mathrm{~Hz}, 1 \mathrm{H}), 3.15(\mathrm{~d}, J=6.94 \mathrm{~Hz}, 2 \mathrm{H}), 1.19-1.31(\mathrm{~m}, 1 \mathrm{H}), 0.46-$ $0.66(\mathrm{~m}, 2 \mathrm{H}), 0.23-0.41(\mathrm{~m}, 2 \mathrm{H})$. LC-MS: $m / z 519[\mathrm{M}+\mathrm{H}]^{+}, t_{\mathrm{R}}=$ $2.24 \mathrm{~min}$.

4-[[3-[3-(Cyclopropylmethyl)-8-(trifluoromethyl) $[1,2,4]$ triazolo[4,3-a]pyridin-7-yl]phenyl]carbamoyl]benzenesulfonyl Fluoride (3). Starting from $7 \mathbf{b}(0.260 \mathrm{~g}, 0.7824 \mathrm{mmol})$ and $\mathbf{8 b}(0.192$ $\mathrm{mg}, 0.9388 \mathrm{mmol}$ ) and following the procedure described for 2, compound 3 was obtained $(0.274 \mathrm{~g}, 68 \%) .{ }^{1} \mathrm{H}$ NMR $(500 \mathrm{MHz}$, DMSO- $\left.d_{6}\right) \delta 10.83(\mathrm{~s}, 1 \mathrm{H}), 8.76(\mathrm{~d}, J=7.22 \mathrm{~Hz}, 1 \mathrm{H}), 8.22-8.42(\mathrm{~m}$, $4 \mathrm{H}), 7.81-7.99(\mathrm{~m}, 2 \mathrm{H}), 7.54(\mathrm{t}, J=7.80 \mathrm{~Hz}, 1 \mathrm{H}), 7.21(\mathrm{~d}, J=7.80$ $\mathrm{Hz}, 1 \mathrm{H}), 6.96(\mathrm{~d}, J=7.22 \mathrm{~Hz}, 1 \mathrm{H}), 3.15(\mathrm{~d}, J=6.65 \mathrm{~Hz}, 2 \mathrm{H}), 1.12-$ $1.37(\mathrm{~m}, 1 \mathrm{H}), 0.46-0.66(\mathrm{~m}, 2 \mathrm{H}), 0.23-0.42(\mathrm{~m}, 2 \mathrm{H})$. LC-MS: $m / z$ $519[\mathrm{M}+\mathrm{H}]^{+}, t_{\mathrm{R}}=2.24 \mathrm{~min}$.

4-[[4-[3-(Cyclopropylmethyl)-8-(trifluoromethyl)[1,2,4]triazolo[4,3-a]pyridin-7-yl]phenyl]methylcarbamoyl]benzenesulfonyl Fluoride (4). $7 \mathrm{c}(0.050 \mathrm{~g}, 0.144 \mathrm{mmol})$ in 1,4-dioxane $(0.5$ $\mathrm{mL})$ was added to $8 \mathbf{b}(0.038 \mathrm{~g}, 0.173 \mathrm{mmol})$. The resulting suspension was heated at $90{ }^{\circ} \mathrm{C}$ for $30 \mathrm{~min}$. After cooling, the suspension was filtered, washed with $\mathrm{Et}_{2} \mathrm{O}$, and dried under vacuum. The crude product was purified by flash column chromatography (silica; $\mathrm{CH}_{2} \mathrm{Cl}_{2}$ in $\mathrm{MeOH} 100 / 0$ to $94 / 6)$ to give 4 as a white solid (0.025 g, 33\%). ${ }^{1} \mathrm{H}$ NMR $\left(400 \mathrm{MHz}\right.$, DMSO- $\left.d_{6}\right) \delta 9.55(\mathrm{t}, J=5.90 \mathrm{~Hz}, 1 \mathrm{H}), 8.73(\mathrm{~d}, J=$ $6.94 \mathrm{~Hz}, 1 \mathrm{H}), 8.13-8.39(\mathrm{~m}, 4 \mathrm{H}), 7.31-7.55(\mathrm{~m}, 1 \mathrm{H}), 6.92(\mathrm{~d}, J=$ $7.40 \mathrm{~Hz}, 1 \mathrm{H}), 4.62(\mathrm{~d}, J=6.01 \mathrm{~Hz}, 2 \mathrm{H}), 3.13(\mathrm{~d}, J=6.70 \mathrm{~Hz}, 2 \mathrm{H})$, 1.14-1.31 (m, 2H), 0.45-0.62 (m, 2H), 0.20-0.40 (m, 2H). LC-MS: $\mathrm{m} / z 533[\mathrm{M}+\mathrm{H}]^{+}, t_{\mathrm{R}}=2.13 \mathrm{~min}$.

4-[3-(Cyclopropylmethyl)-8-(trifluoromethyl)[1,2,4]triazolo[4,3-a]pyridin-7-yl]aniline (7a). $\mathrm{Pd}\left(\mathrm{PPh}_{3}\right)_{4}(0.075 \mathrm{~g}, 0.065 \mathrm{mmol})$ was added to a stirred suspension of $5(0.300 \mathrm{~g}, 1.0883 \mathrm{mmol})$ and $6 \mathrm{a}$ $(0.164 \mathrm{~g}, 1.197 \mathrm{mmol})$ in a saturated aqueous solution of $\mathrm{NaHCO}_{3}(2$ $\mathrm{mL})$ and 1,4-dioxane $(5 \mathrm{~mL})$. The mixture was heated at $150{ }^{\circ} \mathrm{C}$ for 15 min under microwave irradiation, then cooled to room temperature and filtered through a Celite pad. The filtrate was diluted with water $(20 \mathrm{~mL})$ and extracted with EtOAc $(2 \times 15 \mathrm{~mL})$. The organic layer was washed with brine $(15 \mathrm{~mL})$, dried over anhydrous $\mathrm{Na}_{2} \mathrm{SO}_{4}$, and concentrated in vacuo. The crude was purified by flash column chromatography (silica gel, $\mathrm{MeOH}-\mathrm{NH}_{3}$ in $\mathrm{CH}_{2} \mathrm{Cl}_{2}, 0 / 100$ to 5/95) to give the desired product $7 \mathrm{a}$ as a pale yellow solid $(0.227 \mathrm{~g}, 61 \%)$. LC-MS: $m / z 333[\mathrm{M}+\mathrm{H}]^{+}, t_{\mathrm{R}}=1.62 \mathrm{~min}$.

3-[3-(Cyclopropylmethyl)-8-(trifluoromethyl)[1,2,4]triazolo[4,3-a]pyridin-7-yl]aniline (7b). Starting from 5 (0.300 g, 1.0883 $\mathrm{mmol})$ and $\mathbf{6 b}(0.208 \mathrm{~g}, 1.197 \mathrm{mmol})$ and following the procedure described for $7 \mathbf{a}$, compound $7 \mathbf{b}$ was obtained as a pale yellow solid $(0.265 \mathrm{~g}, 68 \%)$. LC-MS: $m / z 333[\mathrm{M}+\mathrm{H}]^{+}, t_{\mathrm{R}}=1.64 \mathrm{~min}$.

[4-[3-(Cyclopropylmethyl)-8-(trifluoromethyl) [1,2,4]triazolo[4,3-a]pyridin-7-yl]phenyl]methanamine (7c). Starting from 5 $(0.300 \mathrm{~g}, 1.0883 \mathrm{mmol})$ and $6 \mathrm{c}(0.279 \mathrm{~g}, 1.197 \mathrm{mmol})$ and following the procedure described for $7 \mathrm{a}$, compound $7 \mathrm{c}$ was obtained as a pale yellow solid (0.245 g, 65\%). LC-MS: $m / z 347[\mathrm{M}+\mathrm{H}]^{+}, t_{\mathrm{R}}=1.5$ min.

Biology. Cell Culture. CHO-K1 cells (CCL-61; ATCC, Rockville, MD, USA) were grown in Dulbecco's modified Eagle's medium/ nutrient F-12 Ham (DMEM/F12) supplemented with 10\% (v/v) fetal calf serum, $100 \mathrm{IU} \cdot \mathrm{mL}^{-1}$ penicillin, $100 \mu \mathrm{g} \cdot \mathrm{mL}^{-1}$ streptomycin, and $100 \mathrm{mM}$ pyruvate. $\mathrm{CHO}-\mathrm{K} 1$ cells stably expressing the wild-type (WT) $\mathrm{hmGlu}_{2}$ receptor (CHO-K1 $\mathrm{hmGlu}_{2}$; Janssen Research and Development) were grown in Dulbecco's modified Eagle's medium (DMEM) supplemented with $10 \%(\mathrm{v} / \mathrm{v})$ fetal calf serum, $200 \mathrm{IU} \cdot \mathrm{mL}^{-1}$ penicillin, $200 \mu \mathrm{g} \cdot \mathrm{mL}^{-1}$ streptomycin, $30.5 \mu \mathrm{g} \cdot \mathrm{mL}^{-1} \mathrm{~L}$-proline, and 400 $\mu \mathrm{g} \cdot \mathrm{mL}^{-1} \mathrm{G} 418$. All cells were grown at $37^{\circ} \mathrm{C}$ and $5 \% \mathrm{CO}_{2}$ and were subcultured at a ratio of 1:10 twice every week.

Plasmids and Transient Transfection. cDNA encoding human mutated and nonmutated $\mathrm{mGlu}_{2}$ receptors were synthesized by GeneArt (Life Technologies, Carlsbad, CA, USA), subcloned to the pcDNA3.1(+) expression vector (Life Technologies) and amplified by E. coli transformation. At 24 hours before transfection, cells were seeded in $15 \mathrm{~cm} \varnothing$ culture plates at high density $\left(20000\right.$ cells $\left./ \mathrm{cm}^{2}\right)$. Transient transfections in CHO-K1 cells were performed using the cationic lipid transfection reagent LTX Lipofectamine reagent (Life Technologies).

Cell Membrane Preparation. CHO-K1 hmGlu ${ }_{2}$ cells in DMEM without G418 were plated into $15 \mathrm{~cm} \varnothing$ plates. Upon growth to $70 \%$ confluency sodium butyrate (final concentration $5 \mathrm{mM}$ ) was added to the plates. ${ }^{42}$ After $24 \mathrm{~h}$, cells were detached by scraping into $5 \mathrm{~mL}$ of PBS and subsequently centrifuged at $1500 \mathrm{rpm}$ for $5 \mathrm{~min}$. Pellets were resuspended in ice-cold Tris buffer $(50 \mathrm{mM}$ Tris- $\mathrm{HCl}, \mathrm{pH} 7.4)$ and homogenized using an Ultra Turrax homogenizer at $24000 \mathrm{rpm}$ (IKAWerke GmbH \& Co.KG, Staufen, Germany). Membranes and the cytosolic fraction were separated by centrifugation at $31000 \mathrm{rpm}$ at 4 ${ }^{\circ} \mathrm{C}$ for $20 \mathrm{~min}$ in an Optima LE-80 K ultracentrifuge (Beckman Coulter, Fullerton, CA). After resuspension of pellets in $10 \mathrm{~mL}$ of Tris buffer, the centrifugation and homogenization steps were repeated. The remaining pellets were suspended into assay buffer $(50 \mathrm{mM}$ Tris$\mathrm{HCl}, \mathrm{pH} 7.4,2 \mathrm{mM} \mathrm{CaCl}, 10 \mathrm{mM} \mathrm{MgCl}_{2}$ ) which was followed by homogenization. Aliquots were stored at $-80{ }^{\circ} \mathrm{C}$.

$\left[{ }^{3} \mathrm{H}\right] \mathrm{JNJ}-46281222$ Binding Assays Using CHO-K1_hmGlu Membranes. Membrane homogenates $(15 \mu \mathrm{g})$ and prewetted wheat-germ agglutinin coated SPA beads ( $0.2 \mathrm{mg}$; RPNQ0001, PerkinElmer, Groningen, The Netherlands) were precoupled in assay buffer while gently shaking at room temperature for $30 \mathrm{~min}$. Then, this membrane bead mixture was added to an Isoplate-96 (PerkinElmer) together with $6 \mathrm{nM}\left[{ }^{3} \mathrm{H}\right] \mathrm{JNJ}-46281222$ and increasing concentrations of competing ligand. Nonspecific binding was determined using $10 \mu \mathrm{M}$ JNJ-40068782 (9). ${ }^{43}$ In the case of pre-incubation experiments, $\left[{ }^{3} \mathrm{H}\right] \mathrm{JNJ}-46281222$ was added after a $3 \mathrm{~h}$ pre-incubation of the samples containing membrane and competitor. Plates were counted in a Microbeta $2450^{2}$ Trilux scintillation microplate counter (PerkinElmer) after a $1 \mathrm{~h}$ incubation at $25^{\circ} \mathrm{C}$

For competition association experiments, the plate was rapidly placed in the microplate counter after addition of the membrane homogenates. Plates were recorded for $120 \mathrm{~min}$ measuring every $30 \mathrm{~s}$ at ambient temperature. The assay buffer in these experiments 
contained $1 \mathrm{mM}$ glutamate, as this was shown to induce monophasic association and dissociation. This enabled straightforward determination of kinetic parameters and resembles a condition at which PAMs likely exert their effect under physiological conditions. ${ }^{18}$

$\left[{ }^{3} \mathrm{H}\right] \mathrm{JNJ}-46281222$ Binding Assays Using Transiently Transfected CHO-K1 hmGlu ${ }_{2}$ Membranes. Membrane homogenates (30 or $60 \mu \mathrm{g})$ were diluted in ice-cold assay buffer $(50 \mathrm{mM}$ Tris- $\mathrm{HCl}, \mathrm{pH}$ 7.4, $2 \mathrm{mM} \mathrm{CaCl}_{2}, 10 \mathrm{mM} \mathrm{MgCl}_{2}$ ) to a total reaction volume of $100 \mu \mathrm{L}$ containing increasing concentrations of competing ligand and $6 \mathrm{nM}$ $\left[{ }^{3} \mathrm{H}\right] J \mathrm{NJ}-46281222$. Nonspecific binding was determined using $10 \mu \mathrm{M}$ 9. After $1 \mathrm{~h}$ at $15^{\circ} \mathrm{C}$, incubation was terminated by rapid filtration over GF/C filters through a Brandel harvester 24 (Brandel, Gaithersburg, $\mathrm{MD}, \mathrm{USA}$ ). Filters were subsequently washed at least three times using ice-cold wash buffer (50 mM Tris- $\mathrm{HCl}, \mathrm{pH}$ 7.4). Filter-bound radioactivity was determined using liquid scintillation spectrometry on a TRI-Carb 2810 TR counter (PerkinElmer).

Irreversible Binding of $\left[{ }^{3} \mathrm{H}\right] \mathrm{JNJ}-46281222$ to $\mathrm{CHO}-$ K1_hmGlu 2 and Transiently Transfected $\mathbf{h m G l u}_{2}$ Membranes. Membrane homogenates $(30,60$, or $120 \mu \mathrm{g})$ were chosen such that specific binding was close to $10 \%$ to allow for good resolution and avoid ligand depletion. Samples were incubated with $\mathrm{mGlu}_{2}$ PAMs $1-$ 4 at a $10 \times \mathrm{IC}_{50}$ concentration in a total volume of $400 \mu \mathrm{L}(\mathrm{CHO}-$ $\mathrm{K} 1 \_\mathrm{hmGlu}{ }_{2}$ membranes) assay buffer containing $1 \mathrm{mM}$ glutamate in Eppendorf tubes. $0.25 \%$ DMSO was taken as a control for total binding and nonspecific binding.

After incubation for $1 \mathrm{~h}$ at $25^{\circ} \mathrm{C}$ while gently shaking, the samples were centrifuged at $16100 \mathrm{~g}$ at $4{ }^{\circ} \mathrm{C}$ for $5 \mathrm{~min}$. Unbound ligands were removed by aspiration of supernatant. An amount of $1 \mathrm{~mL}$ of assay buffer was added, pellets were resuspended, and samples were incubated for $20 \mathrm{~min}$ at $25{ }^{\circ} \mathrm{C}$. This centrifugation and washing cycle was repeated 4 times. After that, supernatant was removed and the membranes were resuspended in a total volume of $400 \mu \mathrm{L}$ (CHO$\mathrm{K} 1 \_\mathrm{hmGlu} 2$ ) or $100 \mu \mathrm{L}$ (transiently transfected $\mathrm{hmGlu}_{2}$ mutants) containing $6 \mathrm{nM}\left[{ }^{3} \mathrm{H}\right] \mathrm{JNJ}-46281222$ and $1 \mathrm{mM}$ glutamate in tubes. Nonspecific binding was determined using $10 \mu \mathrm{M}$ 9. After $1 \mathrm{~h}$ incubation at $25{ }^{\circ} \mathrm{C}$, incubations were terminated and samples obtained and analyzed as described under " $\left[{ }^{3} \mathrm{H}\right] J \mathrm{NJ}-46281222$ Binding" sections.

$\left[{ }^{35}\right.$ S $]$ GTP $\gamma$ S Binding Assays. Membrane homogenates (5 or 10 $\mu \mathrm{g})$ were diluted in ice-cold assay buffer $(50 \mathrm{mM}$ Tris- $\mathrm{HCl}, \mathrm{pH} 7.4$, $100 \mathrm{mM} \mathrm{NaCl}, 3 \mathrm{mM} \mathrm{MgCl}$ ) supplemented with $10 \mu \mathrm{M}$ GDP (Sigma-Aldrich, St. Louis, MO, USA) and $5 \mu \mathrm{g}$ of saponin to a total reaction volume of $80 \mu \mathrm{L}$ containing increasing concentrations of ligand of interest and a glutamate concentration equivalent to its $\mathrm{EC}_{20}$ value $(4 \mu \mathrm{M})$ in the case of a PAM dose-response curve. Basal receptor stimulation was determined using assay buffer, and maximum receptor stimulation was determined using $1 \mathrm{mM}$ glutamate. Samples were preincubated for $30 \mathrm{~min}$ at $25{ }^{\circ} \mathrm{C}$. Subsequently, $20 \mu \mathrm{L}$ of $\left[{ }^{35} \mathrm{~S}\right] \mathrm{GTP} \gamma \mathrm{S}$ (final concentration $0.3 \mathrm{nM}$; PerkinElmer) was added. The reaction was stopped after a $90 \mathrm{~min}$ incubation at $25^{\circ} \mathrm{C}$ by rapid filtration through a 96-well GF/B filterplate (PerkinElmer) on a PerkinElmer FilterMate harvester. Plates were washed with ice-cold wash buffer ( $50 \mathrm{mM}$ Tris-HCl, pH 7.4, $5 \mathrm{mM} \mathrm{MgCl}_{2}$ ). Filter-bound radioactivity was determined by scintillation spectrometry using the Microbeta ${ }^{2}$ counter.

Irreversible Binding to CHO-K1_hmGlu 2 Membranes in a Functional $\left.{ }^{35} \mathrm{~S}\right] \mathrm{GTP} \gamma \mathrm{S}$ Binding Assay. Experiments were performed as described under "Irreversible Binding of $\left[{ }^{3} \mathrm{H}\right] J \mathrm{NJ}-46281222$ to CHO-K1 hmGlu 2 and Transiently Transfected hmGlu $\mathrm{hem}_{2}$ branes", with assay buffer as described under " $\left.{ }^{[35} \mathrm{S}\right] \mathrm{GTP} \gamma \mathrm{S}$ Binding Assays". PAMs were diluted in assay buffer containing a glutamate concentration equivalent to its $\mathrm{EC}_{20}$ value $(4 \mu \mathrm{M})$. After the washing steps, membrane suspensions were transferred to tubes in a volume of $360 \mu \mathrm{L}$ of assay buffer containing saponin $(10 \mu \mathrm{g})$ and GDP $(10 \mu \mathrm{M})$. $\mathrm{PAM}$ samples contained an $\mathrm{EC}_{20}$ glutamate concentration, total binding was determined using $1 \mathrm{mM}$ glutamate, and basal $\left[{ }^{35} \mathrm{~S}\right] \mathrm{GTP} \gamma \mathrm{S}$ binding was determined using assay buffer only. Samples were preincubated for $30 \mathrm{~min}$ at $25^{\circ} \mathrm{C}$. Subsequently, $40 \mu \mathrm{L}$ of $\left[{ }^{35} \mathrm{~S}\right] \mathrm{GTP} \gamma \mathrm{S}$ (final concentration $0.3 \mathrm{nM}$ ) was added. The reaction was stopped after a $30 \mathrm{~min}$ incubation at $25{ }^{\circ} \mathrm{C}$ by rapid filtration over GF/B filters through a Brandel harvester 24 (Brandel, Gaithersburg, MD, USA). Filters were subsequently washed at least three times using ice-cold wash buffer ( $50 \mathrm{mM}$ Tris- $\mathrm{HCl}, \mathrm{pH} 7.4,5 \mathrm{mM} \mathrm{MgCl} 2$ ). Samples were analyzed as described under " $\left[{ }^{3} \mathrm{H}\right] \mathrm{JNJ}-46281222$ Binding" sections.

$\left[{ }^{3} \mathrm{H}\right] \mathrm{LY} 341495$ Binding Assays. Membrane homogenates $(5 \mu \mathrm{g})$ were diluted in assay buffer ( $50 \mathrm{mM}$ Tris- $\mathrm{HCl}, \mathrm{pH} 7.4,2 \mathrm{mM} \mathrm{CaCl}_{2}$, $10 \mathrm{mM} \mathrm{MgCl} 2$ ) to a total reaction volume of $100 \mu \mathrm{L}$ containing increasing concentrations of glutamate $(100 \mathrm{nM}$ to $1 \mathrm{mM})$ and $3 \mathrm{nM}$ $\left[{ }^{3} \mathrm{H}\right]$ LY341495 (ARC, St. Louis, MO, USA). Nonspecific binding was determined using $1 \mathrm{mM}$ glutamate. After incubation for $1 \mathrm{~h}$ at $25{ }^{\circ} \mathrm{C}$, samples were rapidly filtered through a 96-well GF/B filterplate (PerkinElmer) on a PerkinElmer filtermate harvester and washed three times with ice-cold wash buffer ( $50 \mathrm{mM}$ Tris-HCl, $\mathrm{pH}$ 7.4). Samples were analyzed as described under "[ $\left.{ }^{3} \mathrm{H}\right] \mathrm{JNJ}-46281222$ Binding" sections.

For all radioligand binding experiments DMSO concentrations were $\leq 0.25 \%$ and radioligand concentrations were chosen such that $<10 \%$ of the amount added was receptor-bound to avoid ligand depletion.

Data Analysis. Data analyses were performed using Prism 7.00 (GraphPad software, San Diego, CA, USA). pIC 50 values were obtained using nonlinear regression curve fitting into a sigmoidal concentration-response curve using the equation $Y=$ Bottom + (Top - Bottom $) /\left(1+10^{\left(X-\log I \mathrm{C}_{50}\right)}\right) \cdot \mathrm{p} K_{\mathrm{i}}$ values were obtained from $\mathrm{pIC}_{50}$ values using the Cheng-Prusoff equation. ${ }^{44} \mathrm{pEC}_{50}$ values were determined using nonlinear regression curve fitting into a sigmoidal concentration-response curve with variable slope using the equation $Y$ $=$ Bottom $+($ Top - Bottom $) /\left(1+10^{\left(\left(\log E_{50}-X\right) \text {.Hill slope }\right)}\right)$. Association and dissociation rate constants for unlabeled $\mathrm{mGlu}_{2}$ PAMs were determined by nonlinear regression analysis of competition association data as described by Motulsky and Mahan. ${ }^{31}$ In these equations $k_{1}$ and $k_{2}$ represent the $k_{\text {on }}$ and $k_{\text {off }}$ of $\left[{ }^{3} \mathrm{H}\right] \mathrm{JNJ}-46281222$, which are described in Table 1.

$$
\begin{aligned}
& K_{\mathrm{A}}=k_{1}[\mathrm{~L}] \cdot 10^{-9}+k_{2} \\
& K_{\mathrm{B}}=k_{3}[\mathrm{I}] \cdot 10^{-9}+k_{4} \\
& S=\sqrt{\left(K_{\mathrm{A}}-K_{\mathrm{B}}\right)^{2}+4 k_{1} k_{3} L I \cdot 10^{-18}} \\
& K_{\mathrm{F}}=0.5\left(K_{\mathrm{A}}+K_{\mathrm{B}}+S\right) \\
& K_{\mathrm{S}}=0.5\left(K_{\mathrm{A}}+K_{\mathrm{B}}-S\right) \\
& Q=\frac{B_{\max } k_{1} L \cdot 10^{-9}}{K_{\mathrm{F}}-K_{\mathrm{S}}} \\
& Y=Q\left(\frac{k_{4}\left(K_{F}-K_{\mathrm{S}}\right)}{K_{\mathrm{F}} K_{\mathrm{S}}}+\frac{k_{4}-K_{\mathrm{F}}}{K_{\mathrm{F}}} \mathrm{e}^{\left(-K_{\mathrm{F}} X\right)}-\frac{k_{4}-K_{\mathrm{S}}}{K_{\mathrm{S}}} \mathrm{e}^{\left(-K_{\mathrm{S}} X\right)}\right)
\end{aligned}
$$

Data shown represent the mean \pm SEM of at least three individual experiments performed in duplicate. Statistical analysis was performed if indicated, using a one-way ANOVA with Dunnett's post-test or an unpaired Student's $t$ test. Observed differences were considered statistically significant if $p$-values were below 0.05 .

Computational Efforts. mGlu 2 Receptor Homology Model. Method is as described before. ${ }^{18}$ An active state model of the 7TM domain of human $\mathrm{mGlu}_{2}$ receptor (Uniprot code Q14416) bound to $\mathrm{G}$ protein was built using a combination of structural templates. The

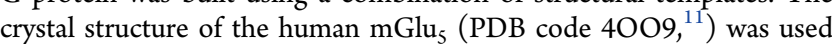
to model all 7TM helices except TM6. ECL2 is not refined in the $\mathrm{mGlu}_{5} \mathrm{X}$-ray structure; therefore this important loop was modeled based on the $\mathrm{mGlu}_{1}$ receptor crystal structure (PDB code $4 \mathrm{OR} 2,{ }^{10}$ ). Finally, the $\beta_{2} \mathrm{AR}$ (PDB code $3 \mathrm{SN} 6,{ }^{45}$ ) active structure was used to model both TM6 in its distinct open conformation and the corresponding $\mathrm{G}$ protein. The sequence identity between $\mathrm{mGlu}_{2}$ and mGlu $_{5} 7 \mathrm{TMs}$ is $51 \%$. The initial model was constructed in MOE version 2014.9 (Chemical Computing Group Inc., Montreal, QC, Canada), and then Maestro (Schrodinger LLC, New York, NY, USA) was used for structure preparation. The Protein Preparation tool was used to fix any missing side chains/atoms, PROPKA assigned 
protonation states, the hydrogen bonding network was optimized, and brief minimization was done until no further change of RMSD to within $0.5 \AA$ removed any structural clashes.

Docking of 2. The ligand was prepared for docking using Maestro. Conformational sampling was performed with ConfGen, and multiple conformers were docked into the $\mathrm{mGlu}_{2}$ active state model using Glide $\mathrm{XP}$. As there is no ligand in the $\mathrm{mGlu}_{2}$ model, the docking grid was centered on the ligand position in the $\mathrm{mGlu}_{1}$ receptor structure, based on superposition of $\mathrm{mGlu}_{1}$ and $\mathrm{mGlu}_{2}$. Sampling was increased in the Glide docking by turning on expanded sampling and passing 100 initial poses to postdocking minimization. All other docking parameters were set to the defaults.

\section{ASSOCIATED CONTENT}

\section{S Supporting Information}

The Supporting Information is available free of charge on the ACS Publications website at DOI: 10.1021/acs.jmedchem. 8 b00051.

mGlu receptor selectivity data, evaluation of the effect of mutations on $\left[{ }^{35} \mathrm{~S}\right] \mathrm{GTP} \gamma \mathrm{S}$ binding and displacement of $\left[{ }^{3} \mathrm{H}\right] \mathrm{LY} 341495$ and $\left[{ }^{3} \mathrm{H}\right] \mathrm{JNJ}-46281222$, and detailed information on LC-MS methods to determine purity of the compounds (PDF)

Molecule SMILES strings and bioactivity (CSV)

\section{AUTHOR INFORMATION}

\section{Corresponding Authors}

*G.T.: phone, +34 92524 5777; e-mail, gtresade@its.jnj.com. *A.P.I.: phone, +31 (0)71 527 4651; e-mail, ijzerman@lacdr. leidenuniv.nl.

\section{ORCID $\odot$}

Andrés A. Trabanco: 0000-0002-4225-758X

Gary Tresadern: 0000-0002-4801-1644

Adriaan P. IJzerman: 0000-0002-1182-2259

\section{Author Contributions}

The manuscript was written through contributions of all authors. All authors have given approval to the final version of the manuscript.

Notes

The authors declare no competing financial interest.

\section{ACKNOWLEDGMENTS}

The authors thank Lieve Heylen for technical assistance and members of the wider Janssen mGlu $_{2}$ receptor PAM drug discovery team. This project was financially supported by Vlaams Agentschap Innoveren \& Ondernemen Project Number 120491.

\section{ABBREVIATIONS USED}

AUC, area under the curve; BCA, bicinchoninic acid; $\mathrm{CHO}$, Chinese hamster ovary; DMEM, Dulbecco's modified Eagle's medium; DMSO, dimethyl sulfoxide; GPCR, G proteincoupled receptor; $\left[{ }^{35} \mathrm{~S}\right] \mathrm{GTP} \gamma \mathrm{S}$, guanosine $5^{\prime}-O-[\gamma$-thio $]$ triphosphate; mGlu, metabotropic glutamate; NAM, negative allosteric modulator; PAM, positive allosteric modulator; PBS, phosphate buffered saline; RT, residence time; SEM, standard error of the mean; SPA, scintillation proximity assay; VFT, Venus flytrap domain; 7TM, seven-transmembrane domain

\section{REFERENCES}

(1) Weichert, D.; Gmeiner, P. Covalent Molecular Probes for Class A G Protein-Coupled Receptors: Advances and Applications. ACS Chem. Biol. 2015, 10, 1376-1386.

(2) Nygaard, R.; Zou, Y.; Dror, R. O.; Mildorf, T. J.; Arlow, D. H.; Manglik, A.; Pan, A. C.; Liu, C. W.; Fung, J. J.; Bokoch, M. P.; Thian, F. S.; Kobilka, T. S.; Shaw, D. E.; Mueller, L.; Prosser, R. S.; Kobilka, B. $\mathrm{K}$. The Dynamic Process of $\beta_{2}$-Adrenergic Receptor Activation. Cell 2013, 152, 532-542.

(3) Glukhova, A.; Thal, D. M.; Nguyen, A. T.; Vecchio, E. A.; Jörg, M.; Scammells, P. J.; May, L. T.; Sexton, P. M.; Christopoulos, A. Structure of the Adenosine $A_{1}$ Receptor Reveals the Basis for Subtype Selectivity. Cell 2017, 168, 867-877.

(4) Weichert, D.; Kruse, A. C.; Manglik, A.; Hiller, C.; Zhang, C.; Hubner, H.; Kobilka, B. K.; Gmeiner, P. Covalent Agonists for Studying G Protein-Coupled Receptor Activation. Proc. Natl. Acad. Sci. U. S. A. 2014, 111, 10744-10748.

(5) Niswender, C. M.; Conn, P. J. Metabotropic Glutamate Receptors: Physiology, Pharmacology, and Disease. Annu. Rev. Pharmacol. Toxicol. 2010, 50, 295-322.

(6) Pin, J.-P.; Bettler, B. Organization and Functions of mGlu and $\mathrm{GABA}_{\mathrm{B}}$ Receptor Complexes. Nature 2016, 540, 60-68.

(7) Lindsley, C. W.; Emmitte, K. A.; Hopkins, C. R.; Bridges, T. M.; Gregory, K. J.; Niswender, C. M.; Conn, P. J. Practical Strategies and Concepts in GPCR Allosteric Modulator Discovery: Recent Advances with Metabotropic Glutamate Receptors. Chem. Rev. 2016, 116, 67076741.

(8) Nicoletti, F.; Bockaert, J.; Collingridge, G. L.; Conn, P. J.; Ferraguti, F.; Schoepp, D. D.; Wroblewski, J. T.; Pin, J. P. Metabotropic Glutamate Receptors: From the Workbench to the Bedside. Neuropharmacology 2011, 60, 1017-1041.

(9) Monn, J. A.; Prieto, L.; Taboada, L.; Pedregal, C.; Hao, J.; Reinhard, M. R.; Henry, S. S.; Goldsmith, P. J.; Beadle, C. D.; Walton, L.; Man, T.; Rudyk, H.; Clark, B.; Tupper, D.; Baker, S. R.; Lamas, C.; Montero, C.; Marcos, A.; Blanco, J.; Bures, M.; Clawson, D. K.; Atwell, S.; Lu, F.; Wang, J.; Russell, M.; Heinz, B. A.; Wang, X.; Carter, J. H.; Xiang, C.; Catlow, J. T.; Swanson, S.; Sanger, H.; Broad, L. M.; Johnson, M. P.; Knopp, K. L.; Simmons, R. M. a; Johnson, B. G.; Shaw, D. B.; McKinzie, D. L. Synthesis and Pharmacological Characterization of C4-Disubstituted Analogs of 1S,2S,5R,6S-2Aminobicyclo[3.1.0] hexane-2,6-dicarboxylate: Identification of a Potent, Selective Metabotropic Glutamate Receptor Agonist and Determination of Agonist-Bou. J. Med. Chem. 2015, 58, 1776-1794.

(10) Wu, H.; Wang, C.; Gregory, K. J.; Han, G. W.; Cho, H. P.; Xia, Y.; Niswender, C. M.; Katritch, V.; Meiler, J.; Cherezov, V.; Conn, P. J.; Stevens, R. C. Structure of a Class C GPCR Metabotropic Glutamate Receptor 1 Bound to an Allosteric Modulator. Science 2014, $344,58-64$

(11) Doré, A. S.; Okrasa, K.; Patel, J. C.; Serrano-Vega, M.; Bennett, K.; Cooke, R. M.; Errey, J. C.; Jazayeri, A.; Khan, S.; Tehan, B.; Weir, M.; Wiggin, G. R.; Marshall, F. H. Structure of Class C GPCR Metabotropic Glutamate Receptor 5 Transmembrane Domain. Nature 2014, 511, 557-562.

(12) Christopher, J. A.; Aves, S. J.; Bennett, K. A.; Doré, A. S.; Errey, J. C.; Jazayeri, A.; Marshall, F. H.; Okrasa, K.; Serrano-Vega, M. J.; Tehan, B. G.; Wiggin, G. R.; Congreve, M. Fragment and StructureBased Drug Discovery for a Class C GPCR: Discovery of the mGlu 5 Negative Allosteric Modulator HTL14242 (3-Chloro-5-[6-(5-Fluoropyridin-2-Y1)pyrimidin-4-Y1] benzonitrile). J. Med. Chem. 2015, 58, 6653-6664.

(13) Cid, J. M.; Tresadern, G.; Vega, J. A.; de Lucas, A. I.; Matesanz, E.; Iturrino, L.; Linares, M. L.; Garcia, A.; Andrés, J. I.; Macdonald, G. J.; Oehlrich, D.; Lavreysen, H.; Megens, A.; Ahnaou, A.; Drinkenburg, W.; Mackie, C.; Pype, S.; Gallacher, D.; Trabanco, A. A. Discovery of 3-Cyclopropylmethyl-7-(4-Phenylpiperidin-1-Yl)-8-trifluoromethyl$[1,2,4]$ triazolo[4,3-A]pyridine (JNJ-42153605): A Positive Allosteric Modulator of the Metabotropic Glutamate 2 Receptor. J. Med. Chem. 2012, 55, 8770-8789. 
(14) Cid, J. M.; Duvey, G.; Tresadern, G.; Nhem, V.; Furnari, R.; Cluzeau, P.; Vega, J. A.; de Lucas, A. I.; Matesanz, E.; Alonso, J. M.; Linares, M. L.; Andrés, J. I.; Poli, S. M.; Lutjens, R.; Himogai, H.; Rocher, J.; Macdonald, G. J.; Oehlrich, D.; Lavreysen, H.; Ahnaou, A.; Drinkenburg, W.; Mackie, C.; Trabanco, A. A. Discovery of 1,4Disubstituted 3-Cyano-2-Pyridones: A New Class of Positive Allosteric Modulators of the Metabotropic Glutamate 2 Receptor. J. Med. Chem. 2012, 55, 2388-2405.

(15) Farinha, A.; Lavreysen, H.; Peeters, L.; Russo, B.; Masure, S.; Trabanco, A. A.; Cid, J.; Tresadern, G. Molecular Determinants of Positive Allosteric Modulation of the Human Metabotropic Glutamate Receptor 2. Br. J. Pharmacol. 2015, 172, 2383-2396.

(16) Pérez-Benito, L.; Doornbos, M. L. J.; Cordomí, A.; Peeters, L.; Lavreysen, H.; Pardo, L.; Tresadern, G. Molecular Switches of Allosteric Modulation of the Metabotropic Glutamate 2 Receptor. Structure 2017, 25, 1153-1162.

(17) Doornbos, M. L. J.; Cid, J. M.; Haubrich, J.; Nunes, A.; van de Sande, J. W.; Vermond, S. C.; Mulder-Krieger, T.; Trabanco, A. A.; Ahnaou, A.; Drinkenburg, W. H.; Lavreysen, H.; Heitman, L. H.; IJzerman, A. P.; Tresadern, G. Discovery and Kinetic Profiling of 7Aryl-1,2,4-triazolo[4,3- a ]Pyridines: Positive Allosteric Modulators of the Metabotropic Glutamate Receptor 2. J. Med. Chem. 2017, 60, 6704-6720.

(18) Doornbos, M. L. J.; Pérez-Benito, L.; Tresadern, G.; MulderKrieger, T.; Biesmans, I.; Trabanco, A. A.; Cid, J. M.; Lavreysen, H.; IJzerman, A. P.; Heitman, L. H. Molecular Mechanism of Positive Allosteric Modulation of the Metabotropic Glutamate Receptor 2 by JNJ-46281222. Br. J. Pharmacol. 2016, 173, 588-600.

(19) Lavreysen, H.; Ahnaou, A.; Drinkenburg, W.; Langlois, X.; Mackie, C.; Pype, S.; Lütjens, R.; Le Poul, E.; Trabanco, A. A.; Nuñez, J. M. C. Pharmacological and Pharmacokinetic Properties of JNJ40411813, a Positive Allosteric Modulator of the mGlu2 Receptor. Pharmacol. Res. Perspect. 2015, 3, e00096.

(20) Lavreysen, H.; Langlois, X.; Ver Donck, L.; Cid Nuñez, J. M.; Pype, S.; Lütjens, R.; Megens, A. Preclinical Evaluation of the Antipsychotic Potential of the mGlu2-Positive Allosteric Modulator JNJ-40411813. Pharmacol. Res. Perspect. 2015, 3, e00097.

(21) Salih, H.; Anghelescu, I.; Kezic, I.; Sinha, V.; Hoeben, E.; Van Nueten, L.; De Smedt, H.; De Boer, P. Pharmacokinetic and Pharmacodynamic Characterisation of JNJ-40411813, a Positive Allosteric Modulator of mGluR2, in Two Randomised, Double-Blind Phase-I Studies. J. Psychopharmacol. 2015, 29, 414-425.

(22) Kent, J. M.; Daly, E.; Kezic, I.; Lane, R.; Lim, P.; De Smedt, H.; De Boer, P.; Van Nueten, L.; Drevets, W. C.; Ceusters, M. Efficacy and Safety of an Adjunctive mGlu2 Receptor Positive Allosteric Modulator to a SSRI/SNRI in Anxious Depression. Prog. Neuro-Psychopharmacol. Biol. Psychiatry 2016, 67, 66-73.

(23) Cid, J. M.; Tresadern, G.; Duvey, G.; Lütjens, R.; Finn, T.; Rocher, J.; Poli, S.; Vega, J. A.; de Lucas, A. I.; Matesanz, E.; Linares, M. L.; Andrés, J. I.; Alcazar, J.; Alonso, J. M.; Macdonald, G. J.; Oehlrich, D.; Lavreysen, H.; Ahnaou, A.; Drinkenburg, W.; Mackie, C.; Pype, S.; Gallacher, D.; Trabanco, A. A. Discovery of 1-Butyl-3Chloro-4-(4-Phenyl-1-Piperidinyl)-(1H)-Pyridone (JNJ-40411813): A Novel Positive Allosteric Modulator of the Metabotropic Glutamate 2 Receptor. J. Med. Chem. 2014, 57, 6495-6512.

(24) Cid, J. M.; Tresadern, G.; Vega, J. A.; De Lucas, A. I.; Del Cerro, A.; Matesanz, E.; Linares, M. L.; García, A.; Iturrino, L.; Pérez-Benito, L.; Macdonald, G. J.; Oehlrich, D.; Lavreysen, H.; Peeters, L.; Ceusters, M.; Ahnaou, A.; Drinkenburg, W.; Mackie, C.; Somers, M.; Trabanco, A. A. Discovery of 8-Trifluoromethyl-3-Cyclopropylmethyl7-[(4-(2,4-Difluorophenyl)-1-Piperazinyl)methyl]-1,2,4-triazolo[4,3A]pyridine (JNJ-46356479), a Selective and Orally Bioavailable mGlu2 Receptor Positive Allosteric Modulator (PAM). J. Med. Chem. 2016, 59, 8495-8507.

(25) Cid-Nuñez, J. M.; De Lucas Olivares, A. I.; Trabanco-Suarez, A. A.; MacDonald, G. J. 7-Aryl-1,2,4-triazolo[4,3-A]pyridine Derivatives and Their Use as Positive Allosteric Modulators of mGluR2 Receptors. WO2010130423 A1, 2010.
(26) Narayanan, A.; Jones, L. H. Sulfonyl Fluorides as Privileged Warheads in Chemical Biology. Chem. Sci. 2015, 6, 2650-2659.

(27) Nijmeijer, S.; Engelhardt, H.; Schultes, S.; van de Stolpe, A. C.; Lusink, V.; de Graaf, C.; Wijtmans, M.; Haaksma, E. E. J.; de Esch, I. J. P.; Stachurski, K.; Vischer, H. F.; Leurs, R. Design and Pharmacological Characterization of VUF14480, a Covalent Partial Agonist That Interacts with Cysteine $98^{3.36}$ of the Human Histamine $\mathrm{H}_{4}$ Receptor. Br. J. Pharmacol. 2013, 170, 89-100.

(28) Yang, X.; Dong, G.; Michiels, T. J. M.; Lenselink, E. B.; Heitman, L.; Louvel, J.; IJzerman, A. P. A Covalent Antagonist for the Human Adenosine $A_{2 A}$ Receptor. Purinergic Signalling 2017, 13, 191201.

(29) Kenakin, T.; Jenkinson, S.; Watson, C. Determining the Potency and Molecular Mechanism of Action of Insurmountable Antagonists. J. Pharmacol. Exp. Ther. 2006, 319, 710-723.

(30) Strelow, J. M. A Perspective on the Kinetics of Covalent and Irreversible Inhibition. SLAS Discovery Adv. Life Sci. R\&D 2017, 22, 320.

(31) Motulsky, H. J.; Mahan, L. C. The Kinetics of Competitive Radioligand Binding Predicted by the Law of Mass Action. Mol. Pharmacol. 1984, 25, 1-9.

(32) Xia, L.; de Vries, H.; IJzerman, A. P.; Heitman, L. H. Scintillation Proximity Assay (SPA) as a New Approach to Determine a Ligand's Kinetic Profile. A Case in Point for the Adenosine $A_{1}$ Receptor. Purinergic Signalling 2016, 12, 115-126.

(33) Guo, D.; van Dorp, E. J. H.; Mulder-Krieger, T.; van Veldhoven, J. P. D.; Brussee, J.; IJzerman, A. P.; Heitman, L. H. Dual-Point Competition Association Assay: A Fast and High-Throughput Kinetic Screening Method for Assessing Ligand-Receptor Binding Kinetics. J. Biomol. Screening 2013, 18, 309-320.

(34) Congreve, M.; Oswald, C.; Marshall, F. H. Applying StructureBased Drug Design Approaches to Allosteric Modulators of GPCRs. Trends Pharmacol. Sci. 2017, 38, 837-847.

(35) Tresadern, G.; Cid, J.-M. M.; Trabanco, A. A. QSAR Design of Triazolopyridine mGlu2 Receptor Positive Allosteric Modulators. J. Mol. Graphics Modell. 2014, 53, 82-91.

(36) Harpsøe, K.; Boesgaard, M. W.; Munk, C.; Bräuner-Osborne, H.; Gloriam, D. E. Structural Insight to Mutation Effects Uncover a Common Allosteric Site in Class C GPCRs. Bioinformatics 2017, 33, $1116-1120$

(37) Kling, R. C.; Plomer, M.; Lang, C.; Banerjee, A.; Hübner, H.; Gmeiner, P. Development of Covalent Ligand-Receptor Pairs to Study the Binding Properties of Nonpeptidic Neurotensin Receptor 1 Antagonists. ACS Chem. Biol. 2016, 11, 869-875.

(38) Gregory, K. J.; Velagaleti, R.; Thal, D. M.; Brady, R. M.; Christopoulos, A.; Conn, P. J.; Lapinsky, D. J. Clickable Photoaffinity Ligands for Metabotropic Glutamate Receptor 5 Based on Select Acetylenic Negative Allosteric Modulators. ACS Chem. Biol. 2016, 11, $1870-1879$.

(39) Singh, J.; Petter, R. C.; Baillie, T. A.; Whitty, A. The Resurgence of Covalent Drugs. Nat. Rev. Drug Discovery 2011, 10, 307-317.

(40) Baillie, T. A. Targeted Covalent Inhibitors for Drug Design. Angew. Chem., Int. Ed. 2016, 55, 13408-13421.

(41) Lu, S.; Zhang, J. Designed Covalent Allosteric Modulators: An Emerging Paradigm in Drug Discovery. Drug Discovery Today 2017, 22, 447-453.

(42) Cuisset, L.; Tichonicky, L.; Jaffray, P.; Delpech, M. The Effects of Sodium Butyrate on Transcription Are Mediated through Activation of a Protein Phosphatase. J. Biol. Chem. 1997, 272, 24148-24153.

(43) Lavreysen, H.; Langlois, X.; Ahnaou, A.; Drinkenburg, W.; te Riele, P.; Biesmans, I.; Van der Linden, I.; Peeters, L.; Megens, A.; Wintmolders, C.; Cid, J. M.; Trabanco, A. A.; Andrés, J. I.; Dautzenberg, F. M.; Lütjens, R.; Macdonald, G.; Atack, J. R. Pharmacological Characterization of JNJ-40068782, a New Potent, Selective, and Systemically Active Positive Allosteric Modulator of the mGlu2 Receptor and Its Radioligand [3H]JNJ-40068782. J. Pharmacol. Exp. Ther. 2013, 346, 514-527.

(44) Cheng, Y.; Prusoff, W. H. Relationship between the Inhibition Constant $\left(\mathrm{K}_{\mathrm{I}}\right)$ and the Concentration of Inhibitor Which Causes 50 
per Cent Inhibition $\left(\mathrm{I}_{50}\right)$ of an Enzymatic Reaction. Biochem. Pharmacol. 1973, 22, 3099-3108.

(45) Rasmussen, S. G. F.; DeVree, B. T.; Zou, Y.; Kruse, A. C.; Chung, K. Y.; Kobilka, T. S.; Thian, F. S.; Chae, P. S.; Pardon, E.; Calinski, D.; Mathiesen, J. M.; Shah, S. T. a; Lyons, J. a; Caffrey, M.; Gellman, S. H.; Steyaert, J.; Skiniotis, G.; Weis, W. I.; Sunahara, R. K.; Kobilka, B. K. Crystal Structure of the $\beta_{2}$ Adrenergic Receptor-Gs Protein Complex. Nature 2011, 477, 549-555. 